\title{
Ocena efektywności sposobów zwiększania rozdzielczości danych sejsmicznych w poszukiwaniach węglowodorów w świetle zastosowanej metodyki akwizycji i procedur modyfikacji spektralnej
}

\begin{abstract}
Porównano efektywność sposobów zwiększania rozdzielczości danych sejsmicznych realizowanych na dwóch różnych etapach projektów sejsmicznych $3 \mathrm{D}$, a to w drodze projektowania zaawansowanych schematów akwizycji, umożliwiających uzyskiwanie obrazu falowego o bardzo wysokiej krotności sumowania (rzędu 2260), jak też w drodze stosowania procedur przetwarzania w domenie spektralnej o (autorskiej) nazwie „,modyfikacja spektralna”. Artykuł jest czwartą publikacją omawiającą powyższe zagadnienie w optyce innowacyjnej opracowanej przez autorkę w ramach realizacji jednego z zadań programu Blue Gas - Polski Gaz Łupkowy. Przedstawione w artykule porównania wskazują, że zastosowanie określonej metodyki istotnie zależy od jakości materiału sejsmicznego. W niniejszej pracy wykorzystano obraz falowy uzyskany od zleceniodawcy (migracja czasowa na sumie - migration AFTER STACK). Na podstawie wykonanych porównań należy sądzić, że decyzja o wyborze sposobu zwiększania rozdzielczości powinna brać pod uwagę aspekt ekonomiczny końcowej realizacji.
\end{abstract}

Słowa kluczowe: rozdzielczość danych sejsmicznych, zakres częstotliwości w sejsmicznym obrazie falowym, modyfikacja spektralna obrazu falowego, projektowanie schematu akwizycji, krotność sumowania, inwersja sejsmiczna, profilowanie akustyczne.

\section{Evaluation of the efficiency of the methods of increasing seismic data resolution in exploration of hydrocarbons in light of the applied acquisition methodology and procedures of spectral modification - real case study}

\begin{abstract}
Comparison of the efficiency of the methods for increasing the resolution of seismic data was performed at two different stages of 3D seismic survey design, by creating advanced acquisition schemes to obtain a very high fold-coverage stacking (with the range of 2260), as well as using processing procedures in the spectral domain - "spectral modification". This article is the fourth publication discussing the issue above, developed by the author within one of the tasks of the Blue Gas - Polski Gaz Łupkowy program. The comparison presented in this paper indicates, that the application of a particular methodology, depends on the quality of the seismic data. In this study a wavefield image obtained from the client (After Stack time migration) was used based on the comparisons made, it should be assumed that the decision on choosing the method of increasing the resolution should take into account the economic aspect of the final implementation.
\end{abstract}

Keys words: resolution of seismic data, frequency range of seismic wavefield image, wavefield image spectral modification, seismic survey acquisition design, field-coverage stacking, seismic inversion, acoustic profiling.

\section{Wprowadzenie}

Duże zainteresowanie wykorzystywaniem danych sejsmicznych umożliwiających wysokorozdzielczą interpretację geologiczną zarejestrowanego pola falowego prowadzi do opracowywania różnorodnych technologii pozwalających na po- szerzenie zakresu częstotliwościowego widma amplitudowego trasy sejsmicznej. Działania powyższe podejmowane są zarówno w zakresie przetwarzania zarejestrowanych danych, jak też w zakresie doboru schematów i parametrów akwizycji, 
łącznie z dostosowaniem i wyborem odbiorników zapisujących pole falowe (np. czujniki cyfrowe) [1] i przetwarzanie [2].

W niniejszej publikacji przedstawiono wyniki porównania efektów zwiększania rozdzielczości danych sejsmicznych uzyskanych dwoma różnymi sposobami: w drodze wykorzystania schematu akwizycji, umożliwiającego sumowanie według wspólnego punktu głębokościowego (WPG) o bardzo wysokiej krotności, oraz w drodze modyfikacji kompleksowej charakterystyki spektralnej pola falowego. Artykuł jest kontynuacją wcześniejszego opracowania ([5]), opartego przede wszystkim na danych syntetycznych. Natomiast materiałem, na którym przedstawiono wyniki zadania sformułowanego w tytule, są dane sejsmiczne z koncesji Wierzbica. Początkowo wybrany materiał sejsmiczny, uzyskany na podstawie projektu $2 \mathrm{D}$, nie satysfakcjonował realizatorów projektu, a krótka charakterystyka geologiczna przedstawiona przez prof. Piotra Krzywca i zespół w pełni potwierdza powyższą opinię. Obydwa sposoby zwiększania rozdzielczości zostały uprzednio przetestowane, jak wyżej wspomniano na danych syntetycznych, obliczonych dla modeli wyinterpretowanych z rzeczywistych danych sejsmicznych (koncesja Wierzbica, projekty 2D i 3D).

W konkretnym omawianym przypadku dane sejsmiczne zostały pozyskane w projekcie sejsmiki 3D na koncesji Wierzbica (rejon Wyżyny Lubelskiej). Porównaniu poddano wyniki modyfikacji spektralnej oraz procedury sumowania na wybranym obiekcie geologicznym w przypadku silnie zróżnicowanych parametrów schematu akwizycji oraz bardzo wysokiej krotności sumowania.

\section{Krótka charakterystyka geologiczna obszaru badań}

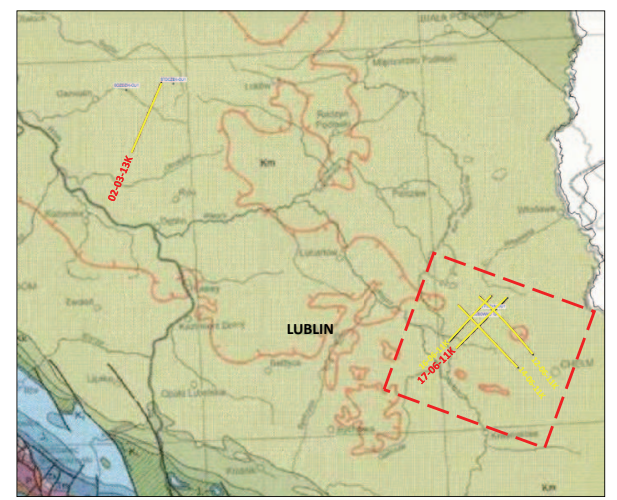

Rys. 1. Mapa geologiczna bez utworów kenozoiku

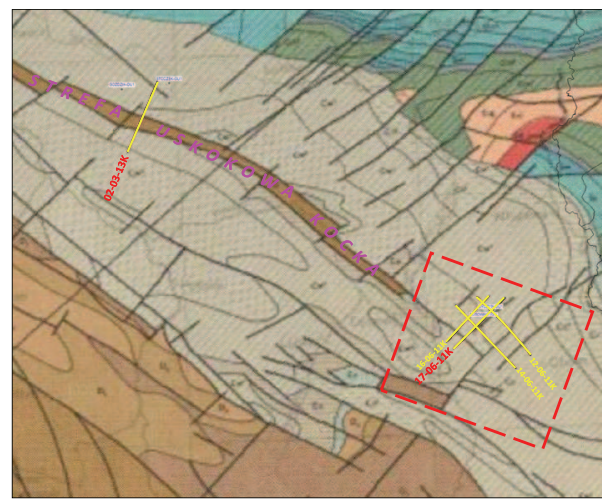

Rys. 2. Mapa geologiczna bez utworów permu i młodszych

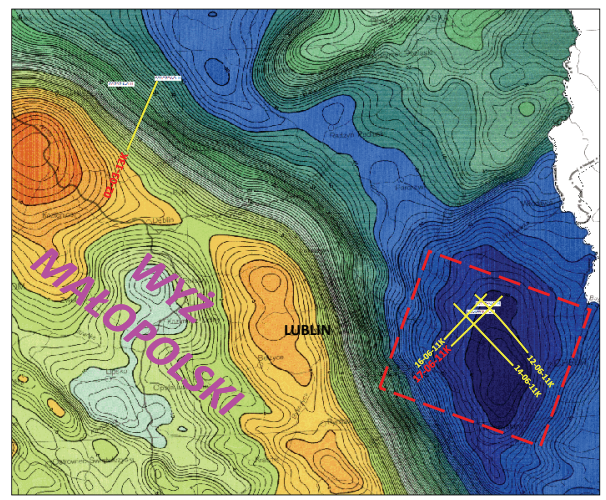

Rys. 3. Mapa grawimetryczna

Przywołując materiały przedstawione przez Piotra Krzywca i Łukasza Słonkę na spotkaniu realizatorów programu „Polskie Technologie dla Gazu Łupkowego" w Krakowie w styczniu 2015 r. (prezentacja prof. Piotra Krzywca, w której wykorzystano m.in. informacje takich autorów jak Dadlez, Pożaryski, Dembowski, Królikowski i Petecki), (rysunki 1, 2 i 3) pokazano kilka informacji charakteryzujących rejon badań, jak też niektóre sekcje sejsmiczne.

Początkowo zadaniem do analizy jest pole falowe zarejestrowane przez Geofizykę Kraków podczas realizacji projektu 2D (rysunek 4). Przykładowe sekcje sejsmiczne (rysunki 5-8) prezentują obraz sejsmiczny, oceniony, szczególnie $\mathrm{w}$ interwale sylurskim i dewońskim, czyli tzw. celu geologicznego, jako słabej i bardzo słabej jakości. Dodatkowo niezbyt precyzyjna (brak kalibracji) informacja z odwierconego tu otworu Syczyn-OU1 powoduje, że wspomniani wyżej autorzy uważają, iż wykonaną interpretację dla utworów dewonu i syluru traktować należy jako hipotetyczną.

Podobnie prezentowane w artykule [3] wyniki oceny rozdzielczości pionowej sekcji sejsmicznej, w nawiązaniu do

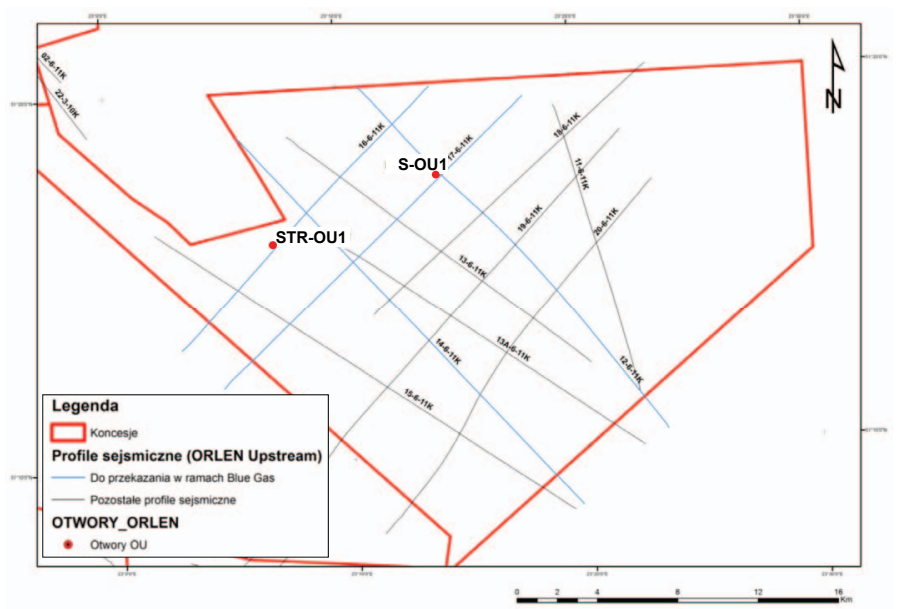

Rys. 4. Schemat akwizycji dla projektu 2D (Geofizyka Kraków)

otworów Syczyn-OU1 i Busówno-IG1, potwierdzają, że wykonanie interpretacji w aspekcie potrzeb procesu szczelinowania jest obarczone nadmiernym ryzykiem.

Powyższe między innymi stało się powodem zaprojektowania przez zespół Akademii Górniczo-Hutniczej - i zrealizowania 


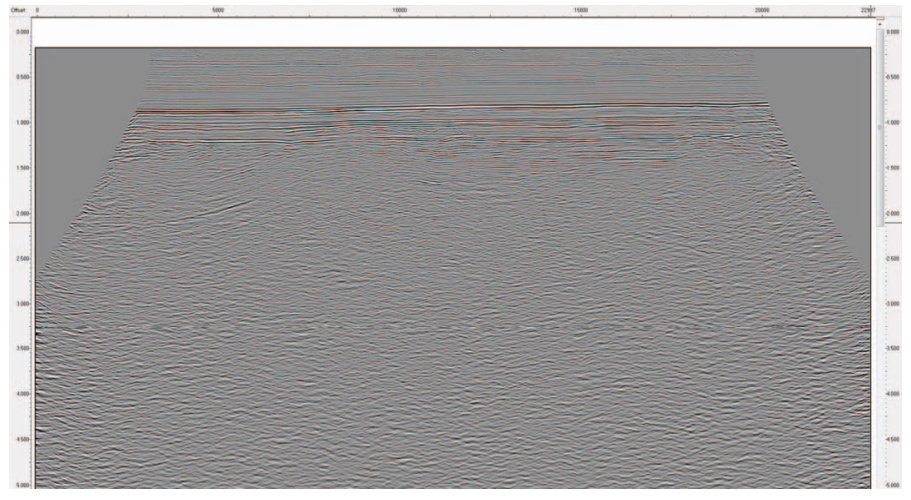

Rys. 5a. Dobra jakość obrazu sejsmicznego dla piętra permsko-mezozoicznego, słaba dla utworów karbonu, bardzo słaba dla utworów dewonu i starszych (według prezentacji P. Krzywca i in., 2015)

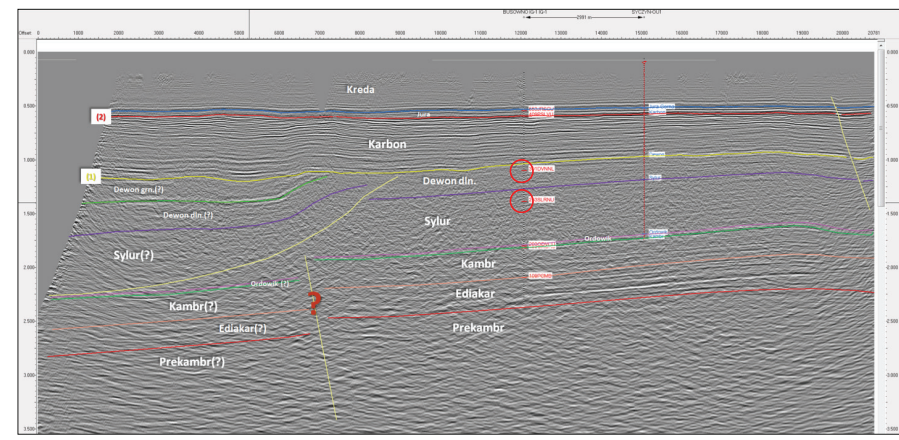

Rys. 6. Ze względu na brak kalibracji otworowej w centralnej i południowo-zachodniej części profilu 17-06-11K interpretację dla dewonu i starszych interwałów należy traktować jako hipotetyczną (według prezentacji P. Krzywca i in., 2015)

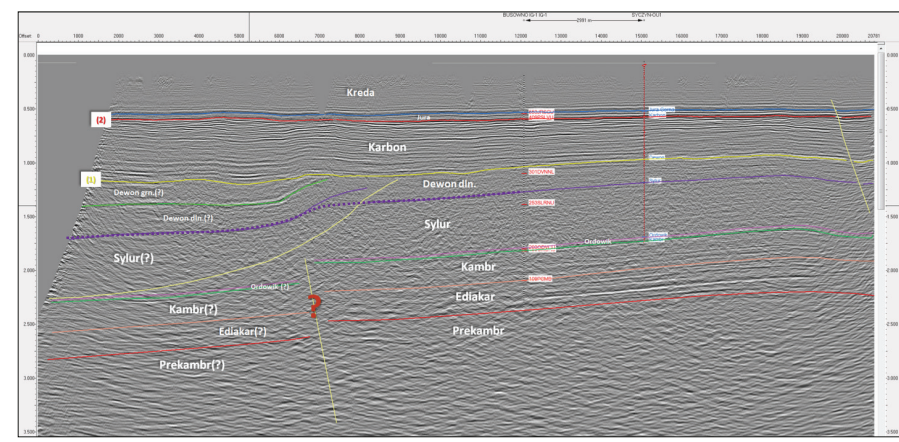

Rys. 8. Alternatywny model dla piętra dewońsko-sylurskiego: ostateczny model ewolucji strefy Kocka będzie miał daleko idące implikacje dla ewolucji pól naprężeń w paleozoiku,

a co za tym idzie - dla modeli powstania naturalnej szczelinowatości (według prezentacji P. Krzywca i in., 2015)

przez zespół Geofizyki Toruń (dla koncesji Wierzbica) - wysokospecjalistycznej akwizycji w opcji sejsmiki 3D. Szkic profili tego projektu przedstawiono na rysunku 9, wybrane krzywe profilowania w otworze $(V p p, \rho)$ i obliczoną krzywą refleksyjności $K$ - na rysunku 10, a przykład zapisanych sekcji sejsmicznych - na rysunku 11 .

Na rysunku $10(a, b, c)$ pokazano krzywe prędkości $V p p$ i VsS zarejestrowane w otworze Str-1.

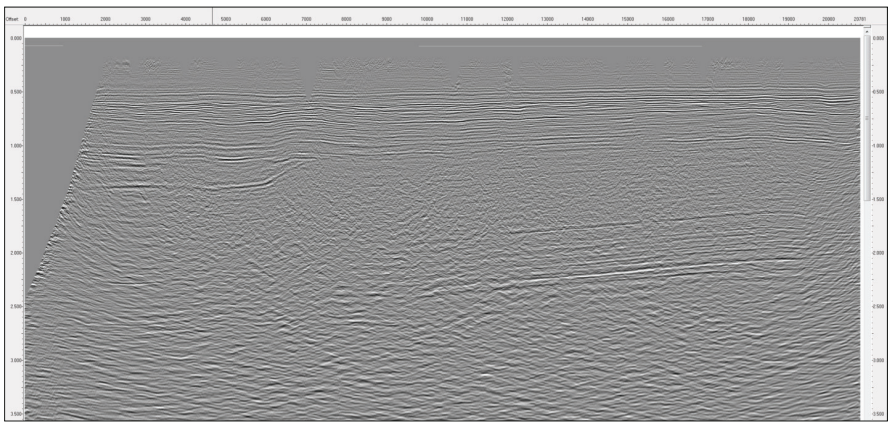

Rys. 5b. Dobrej jakości i ciągłe refleksy widzimy dla utworów jury i kredy. Utwory syluru i dewonu dolnego charakteryzują się znaczną homogenicznością (w przypadku syluru utwory drobnoziarniste, łupki). W części SW profilu obrazowanie utworów dolnego paleozoiku spada niemal do zera (według prezentacji P. Krzywca i in., 2015)

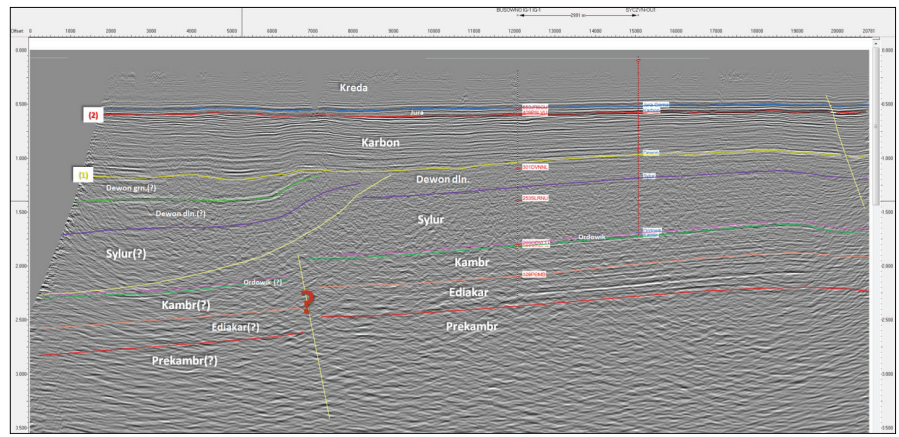

Rys. 7. Podobnie jak wcześniej kolejną opcję interpretacji autorzy traktują z dużym dystansem (według prezentacji P. Krzywca i in., 2015)

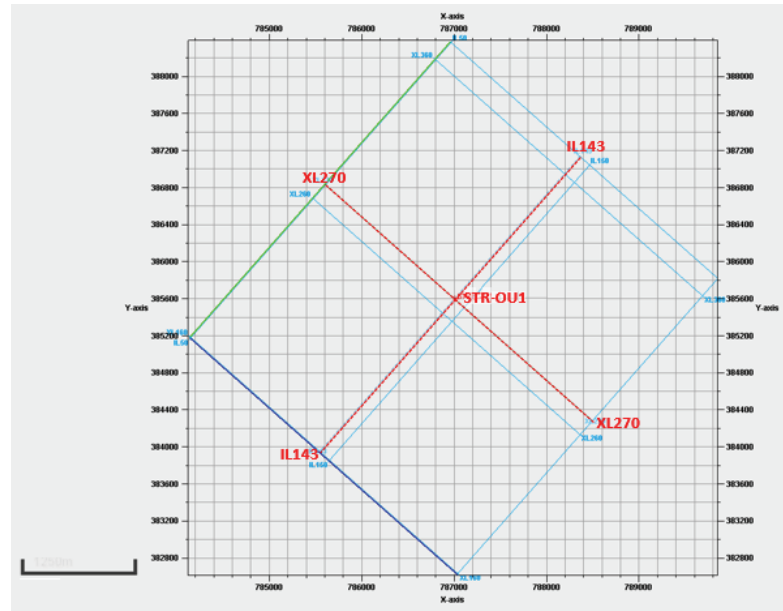

Rys. 9. Szkic profili projektu 3D. Koncesja Wierzbica

Po przeanalizowaniu pokazanych wyżej danych sejsmicznych w wersjach migration BEFORE STACK, AFTER STACK oraz STACK do dalszych analiz w aspekcie rozdzielczości wybrano wersję AFTER STACK. Na tej wersji prowadzono eksperymenty obliczeniowe procedurami modyfikacji spektralnej. W niniejszym artykule starano się pokazać i porównać efektywność dwóch koncepcji zwiększania rozdzielczości. Kontynuując linię modyfikacji spektralnej, szczególną uwagę zwrócono 
Wersja głębokościowa
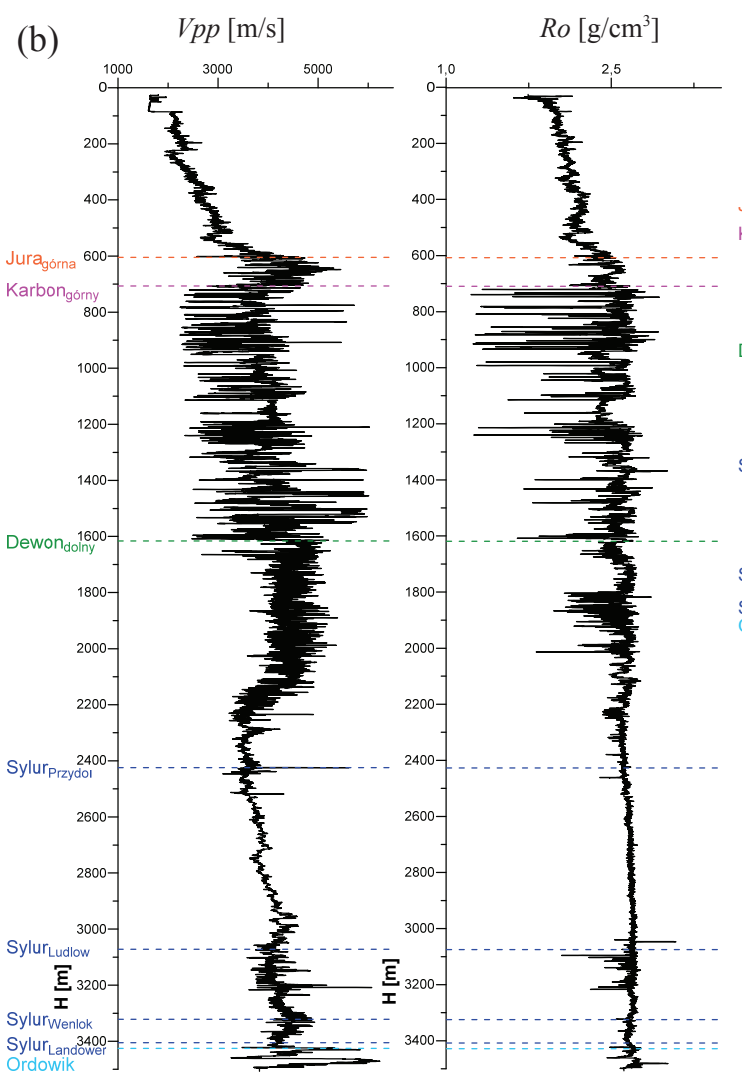

(a)

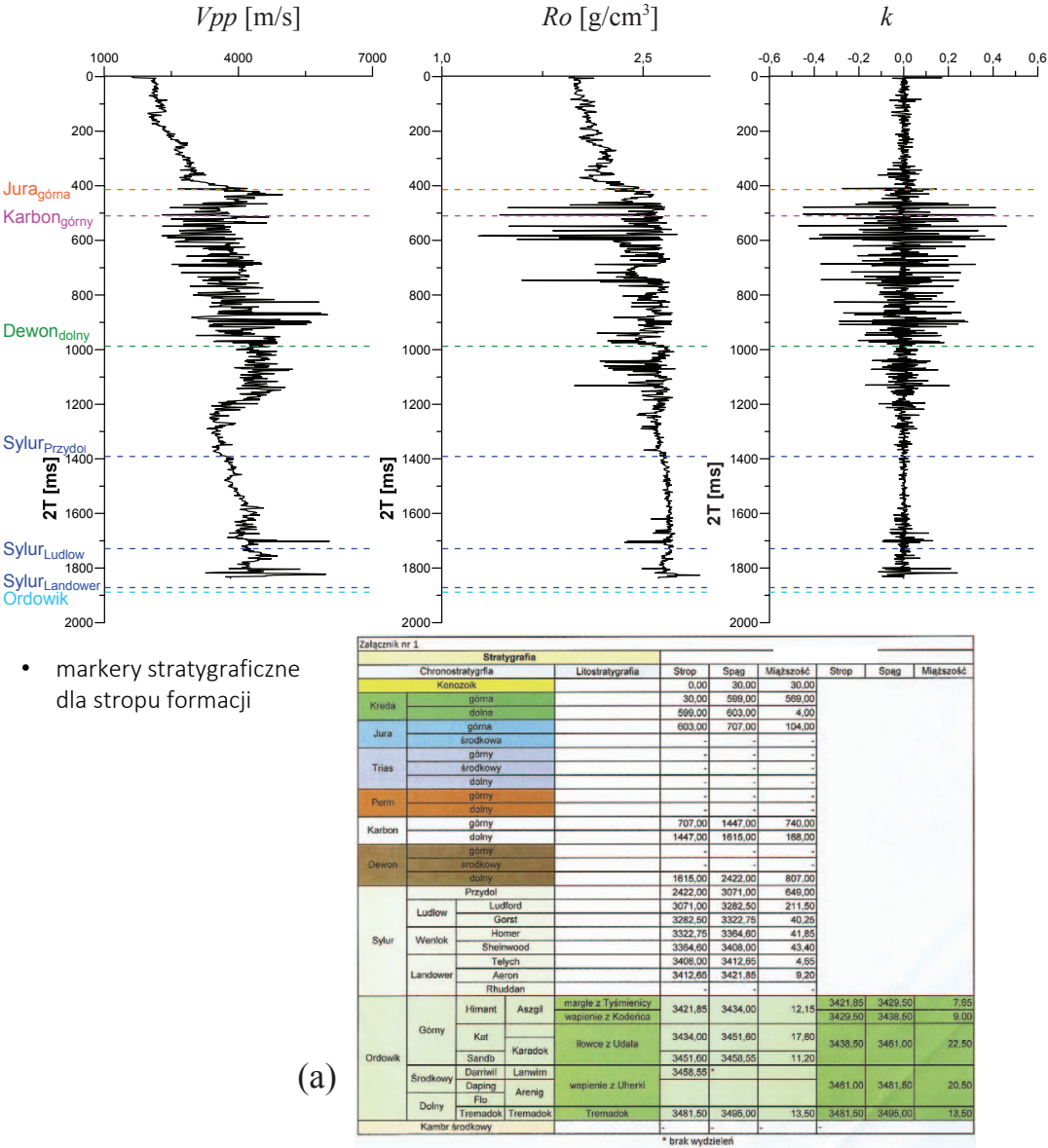

Wersja czasowa dt: $2 \mathrm{~ms}$
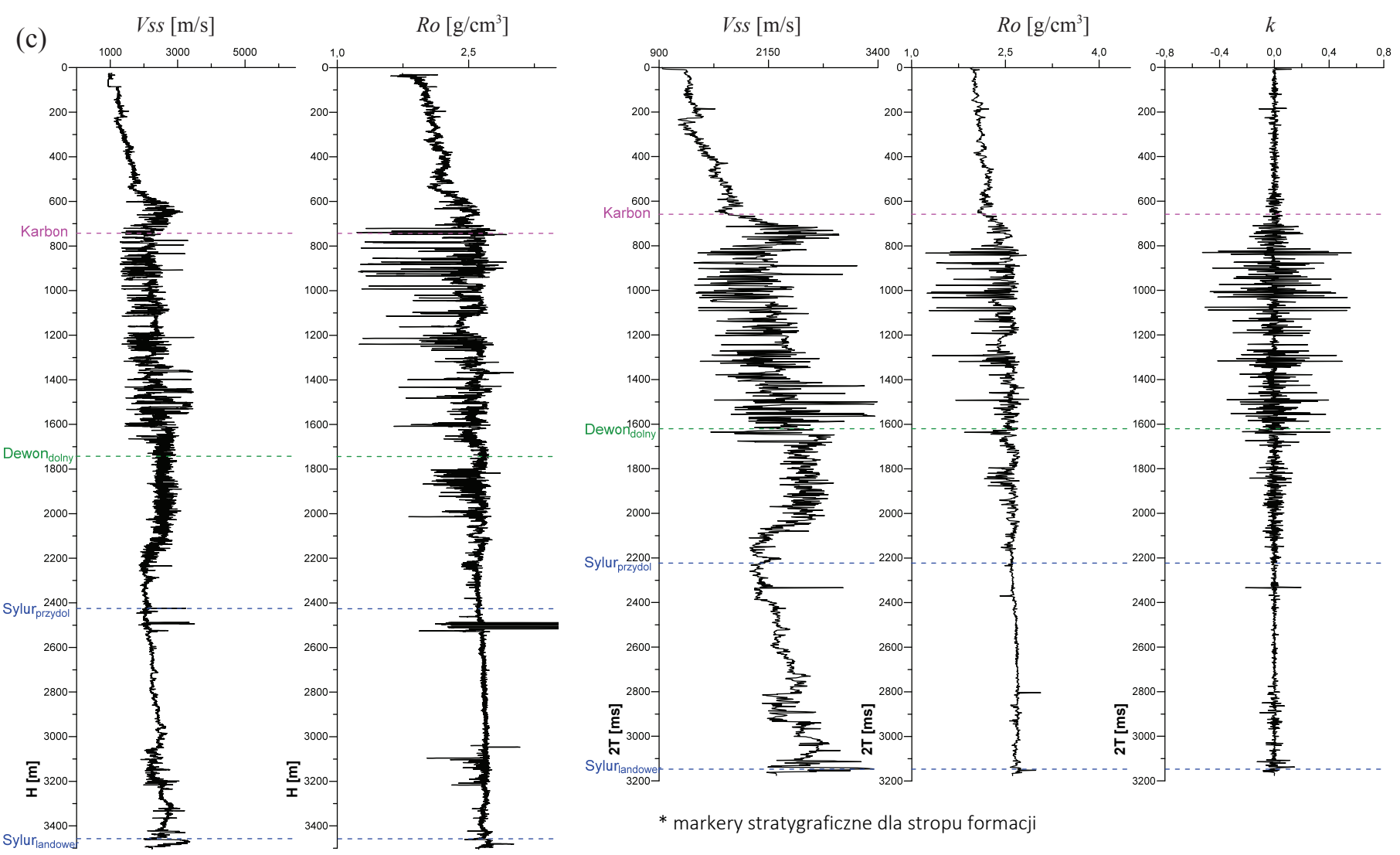

Rys. 10. Ważniejsze poziomy stratygraficzne w analizowanym obszarze (a) oraz dane profilowania akustycznego w domenie głębokości i czasu, zarówno dla fali Vpp (b), jak i VSS (c), wraz z krzywymi refleksyjności obliczonymi według otworu Str-OU1 
Dane wejściowe_STACK

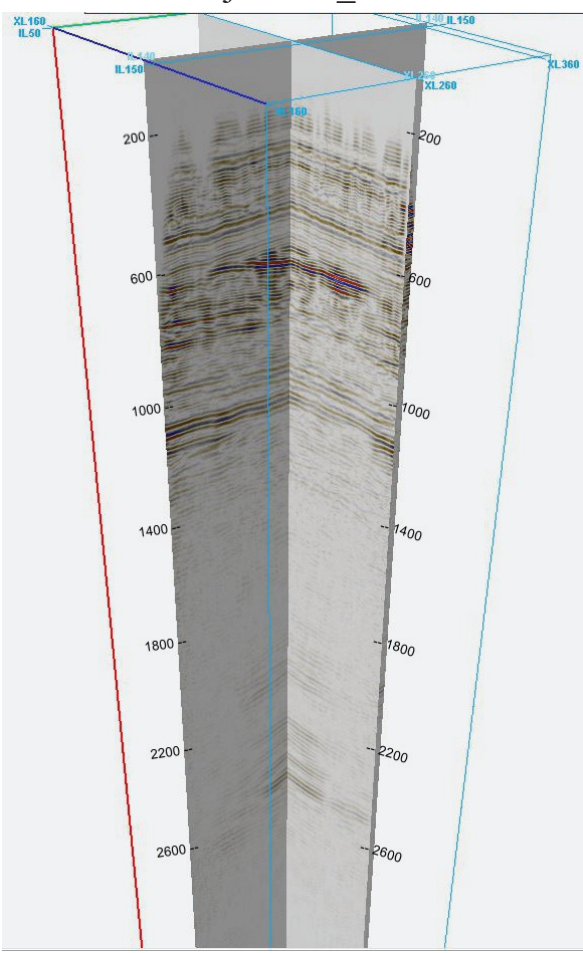

AFTER STACK

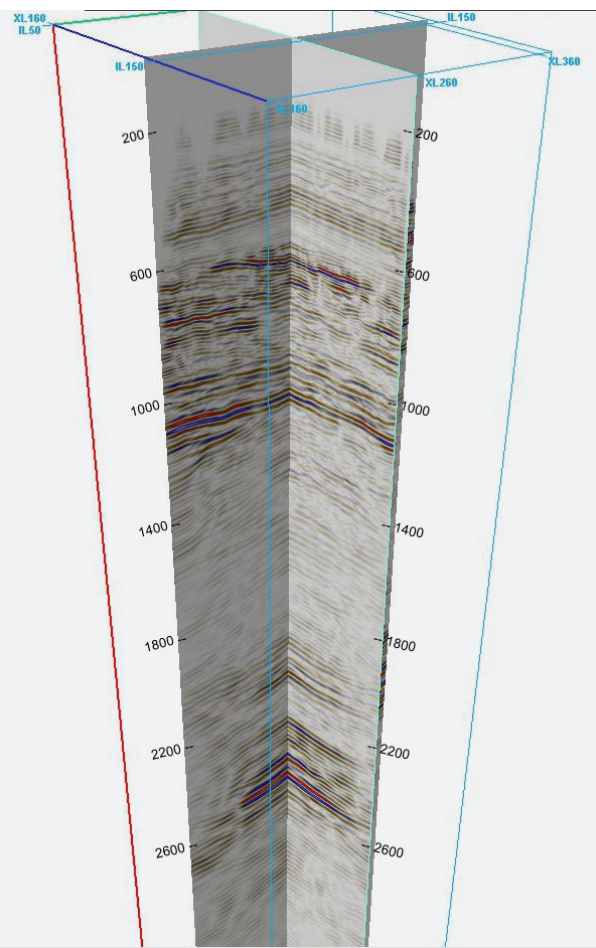

BEFORE STACK

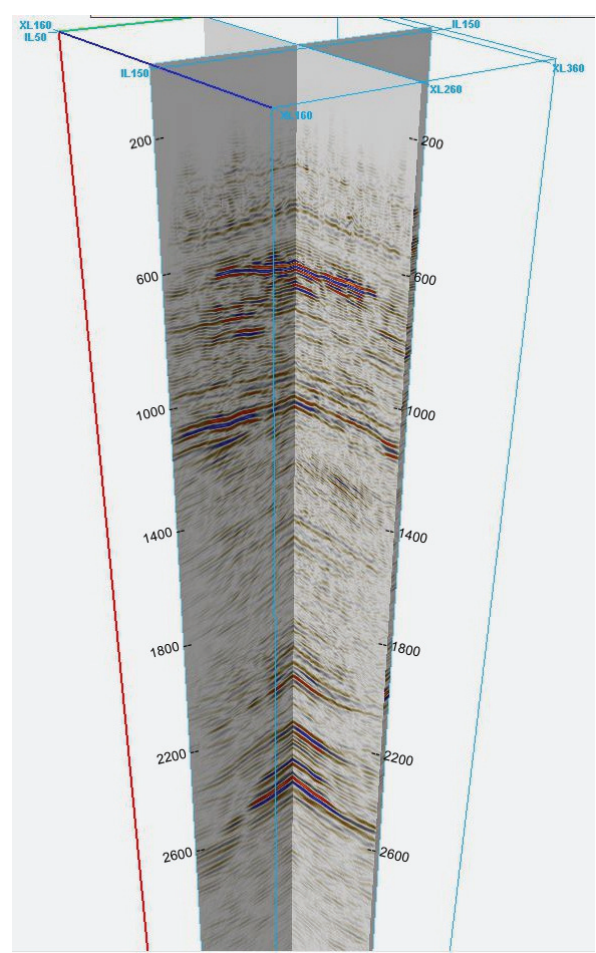

Rys. 11. Dane sejsmiczne poddane modyfikacji

na rozpoznanie charakterystyki spektralnej danych otworowych i danych sejsmicznych, stanowiących źródło informacji dla obliczenia operatora modyfikacji spektralnej.

Jak wspomniano we wcześniejszym artykule przygotowanym w ramach projektu Blue Gas - Polski Gaz Łupkowy [3], ważnym i najtrudniejszym elementem procedury ukierunkowanej na dany obiekt geologiczny jest określenie operatora modyfikacji spektralnej. Optymalizacja i przyspieszenie powyższego procesu są wspomagane:

- równoległą, jednoczesną analizą sejsmicznego pola falowego (w wybranej wersji przetwarzania) oraz funkcji refleksyjności odtworzonej z danych profilowania prędkości i gęstości w otworze, transformowanej z domeny głębokości do domeny czasu,

- modelowaniem sejsmogramów syntetycznych, w zakresach częstotliwości wynikających z rzeczywistych charakterystyk spektralnych obydwu rodzajów danych.

Jak łatwo zaobserwować zarówno na danych sejsmicznych, jak i otworowych, poziomy poniżej dewonu cechują się bardzo słabą refleksyjnością. Ocenę intensywności tych faktów poddano analizie za pomocą modelowania sejsmicznego. W modelowaniu stosowano dwa rodzaje sygnałów elementarnych: zarówno ekstrahowanych $\mathrm{z}$ danych rzeczywistych, jak też typowe sygnały teoretyczne ( $\mathrm{w}$ omawianym przypadku sygnał symetryczny Rickera). Zmieniając częstotliwość sygnału, starano się określić zakres częstotliwości występujących w rzeczywistym polu falowym poprzez analizę charakterystyk spektralnych.
Natomiast specyfika akwizycji zaproponowana przez zespół Katedry Surowców Energetycznych WGGiOŚ AGH, pod kierunkiem prof. Michała Stefaniuka oraz Tomasza Maćkowskiego, pozwala, wykorzystując zaproponowane parametry schematu, manewrować krotnością sumowania, a więc w pewnym sensie wpływać na rozdzielczość sejsmicznego obrazu pola falowego.

Pokazane poniżej wyniki badania obrazu syntetycznego - rysunki 12 (a, b) i 13 (a, b) - sugerują, że dominującą rolę spośród dwóch czynników tworzących trasę syntetyczną (krzywa refleksyjności oraz sygnał elementarny) przyjmuje sygnał, przesuwając cechy ośrodka (krzywą refleksyjności) na dalszy plan.

Analogiczne obserwacje dotyczą zarówno fali podłużnej, jak i poprzecznej. Utwierdza to w przekonaniu, że modyfikacja spektralna jest bardziej wrażliwym narzędziem charakterystyki spektralnej niż transformacja sygnału, a szczególnie do postaci spike [3, 4].

$\mathrm{Na}$ rysunku $14(\mathrm{a}, \mathrm{b})$ przedstawiono analizę widm danych sejsmicznych z zaznaczeniem wyróżniających się przedziałów częstotliwości; jak łatwo zauważyć, określenie tych wielkości w istotnym stopniu zależy od geofizyka - użytkownika. Wyselekcjonowanie częstotliwości obecnych w charakterystyce spektralnej danych otworowych, natomiast nieobecnych w danych sejsmicznych jest ważnym czynnikiem w definiowaniu operatora modyfikacji. Fakt, że zwiększenie rozdzielczości poprzez poszerzanie widma amplitudowego w zakresie wysokich, ale też niskich częstotliwości jedynie na podstawie danych sejsmicznych nie może w pełni sprostać wymaganiu dostosowania sejsmicznego pola falowego do potrzeb odtworzenia obiektu 
(a)

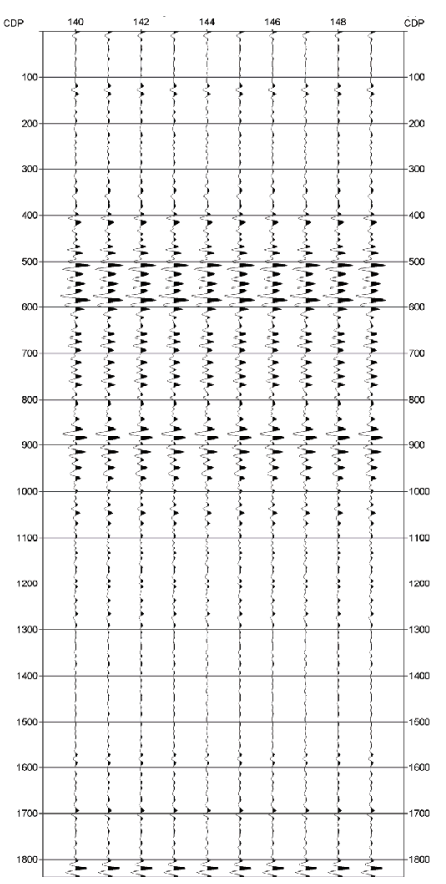

$k$

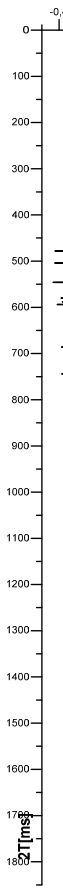

(b)

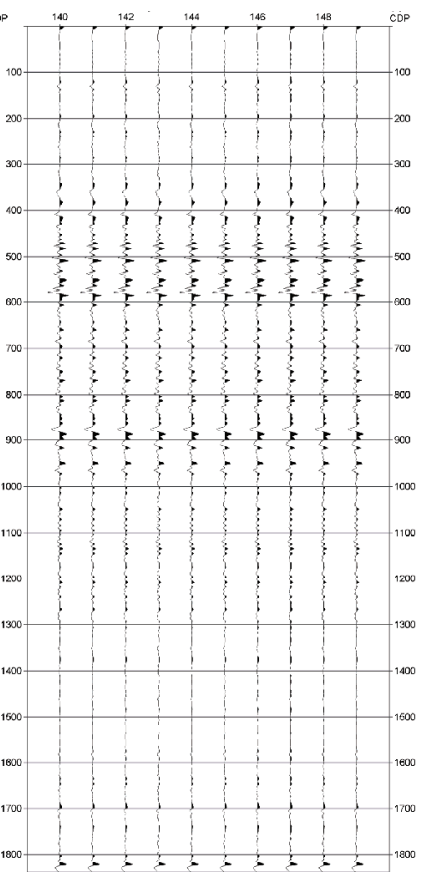

Rys. 12a. Porównanie sejsmogramów teoretycznych obliczonych na podstawie funkcji refleksyjności fali PP z wykorzystaniem różnie pozyskanych sygnałów: (a) ekstrahowanych z sekcji rzeczywistej, (b) przyjętych z albumu sygnałów teoretycznych,

(c) z krzywą refleksyjności z otworu Str-OU1 (na przykładzie propagacji fali PP, $2 T_{\max }=1835 \mathrm{~ms}$ )

$20 \mathrm{~Hz}$

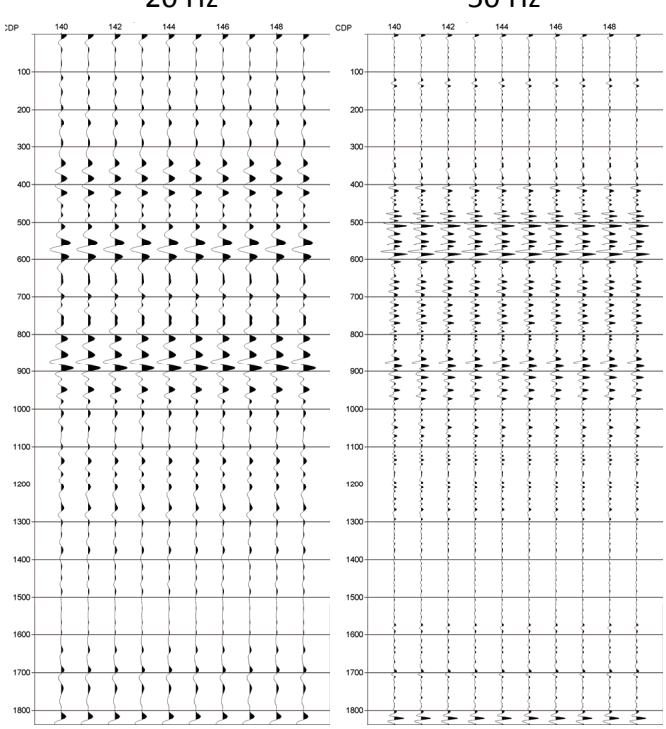

Widma średniej FA z okna 0-1838 ms, trasy 1-10; fala PP Splot Rc z sygnałem Rickera
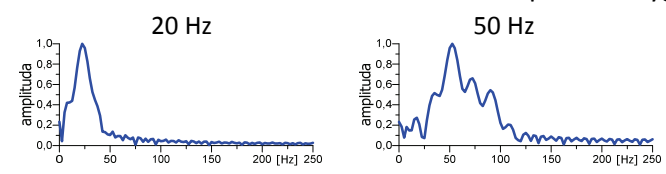

Splot Rc z ekstrahowanym sygnałem minimalnofazowym $R=6$

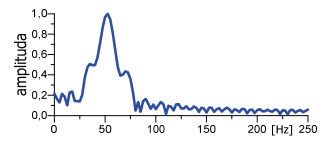

$70 \mathrm{~Hz}$
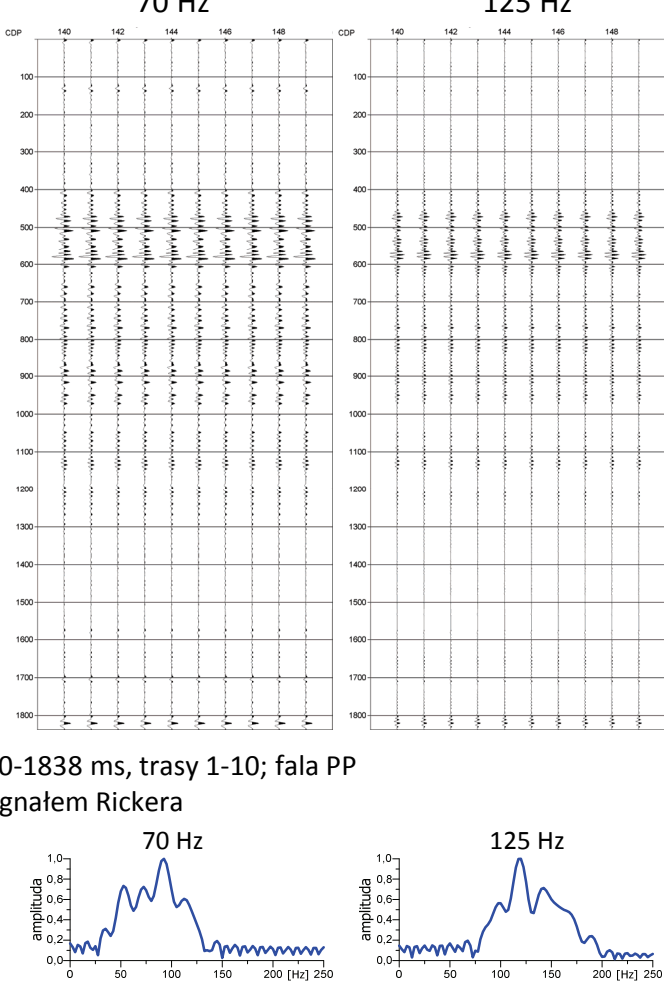

Splot Rc z ekstrahowanym sygnałem symetrycznym $R=32$

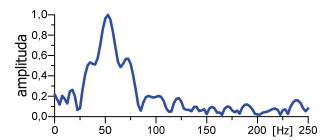

$\Sigma$

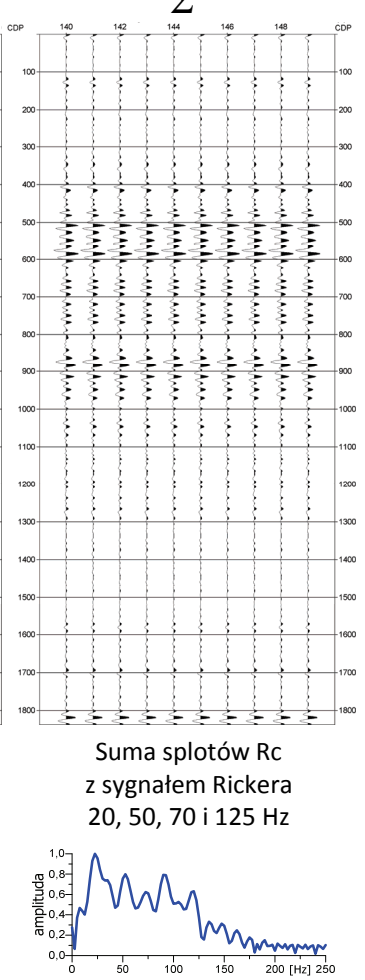

Suma splotów Rc dla $R=6 \mathrm{i} R=32$

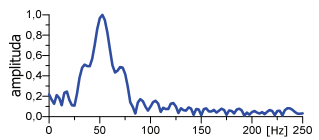

Rys. 12b. Zmiana obrazu falowego wynikająca z udziału różnego zakresu częstotliwości sygnału elementarnego, przy zachowaniu identycznej krzywej refleksyjności, oraz odpowiadające im obliczone widma amplitudowe 
(a)

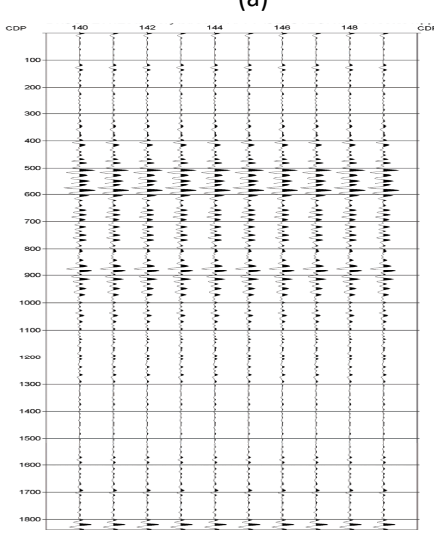

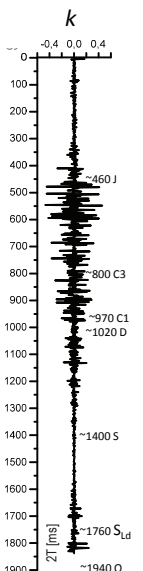

(c)

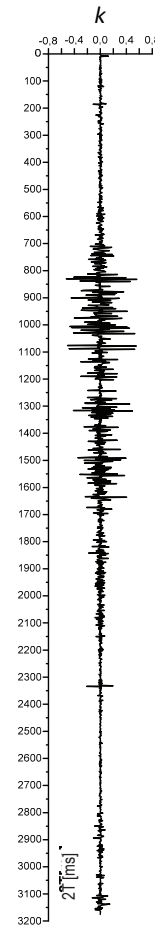

(b)

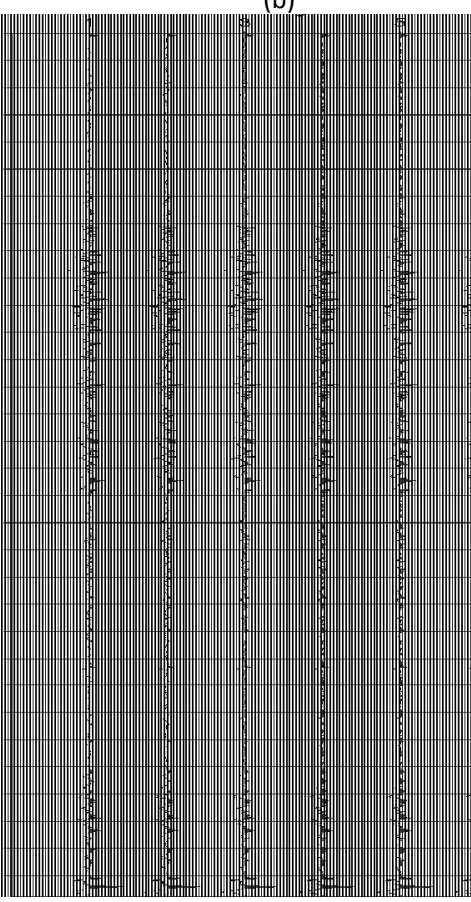

Rys. 13a. Sejsmogramy teoretyczne i krzywe refleksyjności obliczone na podstawie profilowania prędkości fali P (a) i S (b) w otworze (składowa pionowa i radialna c i c')
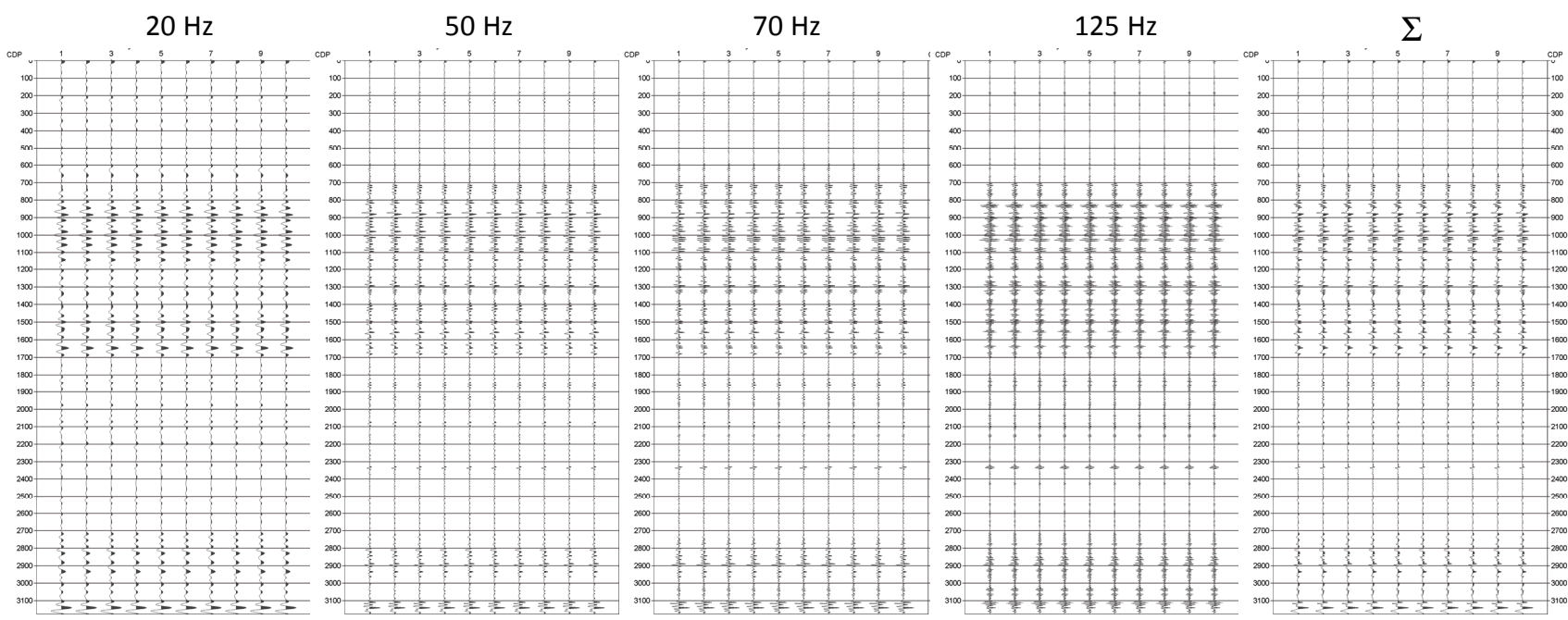

Widma średniej FA z okna 0-3176 ms, trasy 1-10; fala SS Splot Rc z sygnałem Rickera
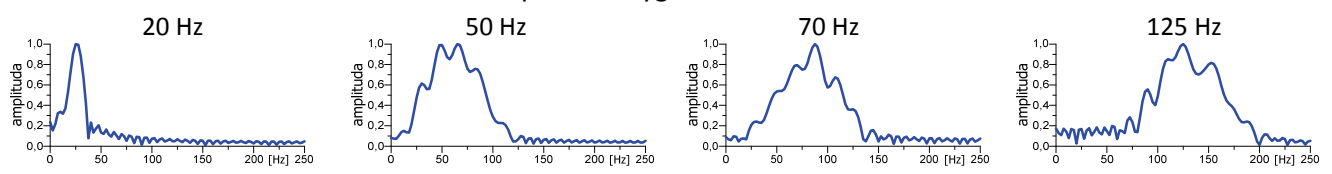

Suma splotów Rc z sygnałem Rickera 20, 50, 70 i $125 \mathrm{~Hz}$

Splot Rc z ekstrahowanym sygnałem minimalnofazowym $R=6$

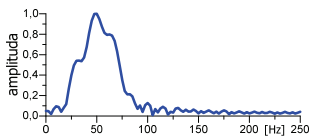

Splot Rc z ekstrahowanym sygnałem symetrycznym $R=32$

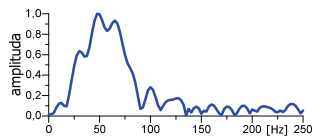

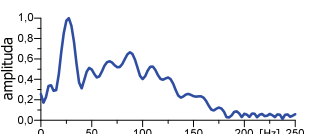

Suma splotów Rc dla $R=6$ i $R=32$

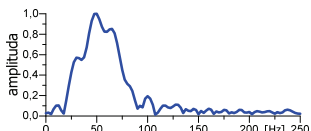

Rys. 13b. Sejsmogramy teoretyczne fali S i odpowiadające im widma FA 

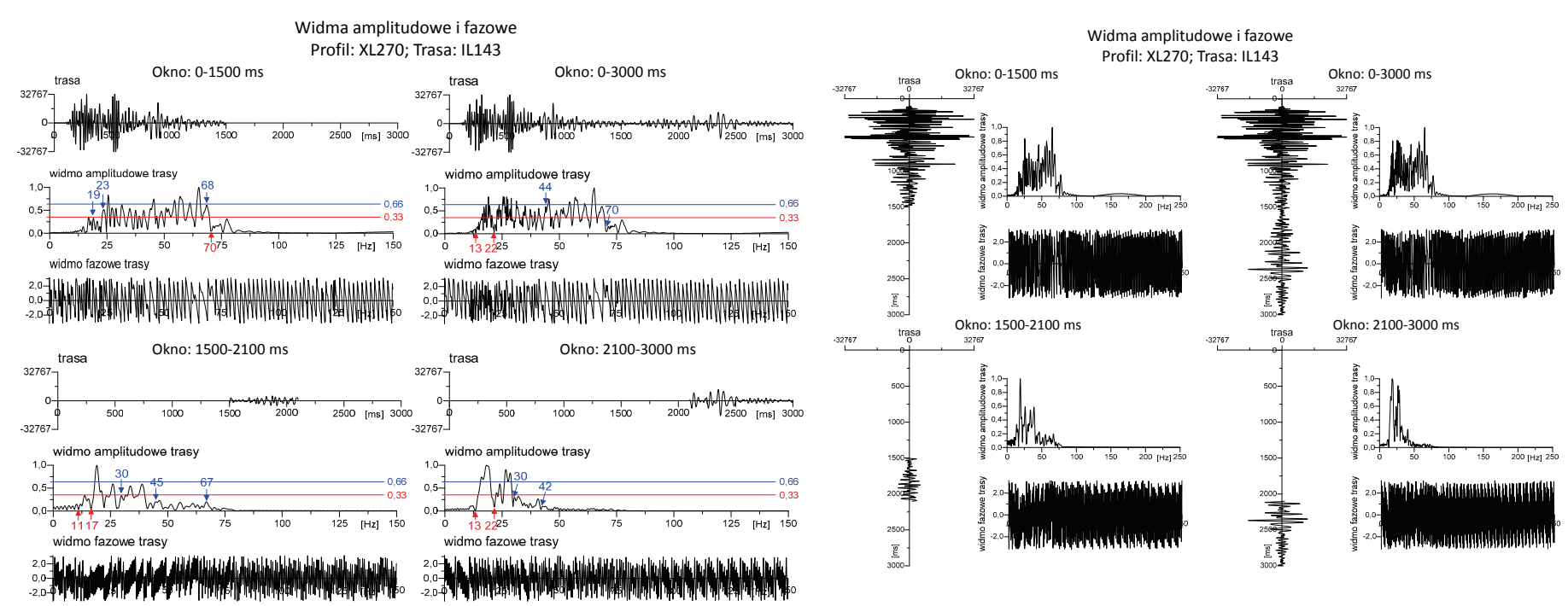

Rys. 14a. Przykład analizy spektralnej trasy sejsmicznej. W zależności od zadanego okna zauważa się eliminację kolejnych częstotliwości. Im większy czas (dłuższa droga propagacji), tym niższy zakres częstotliwości
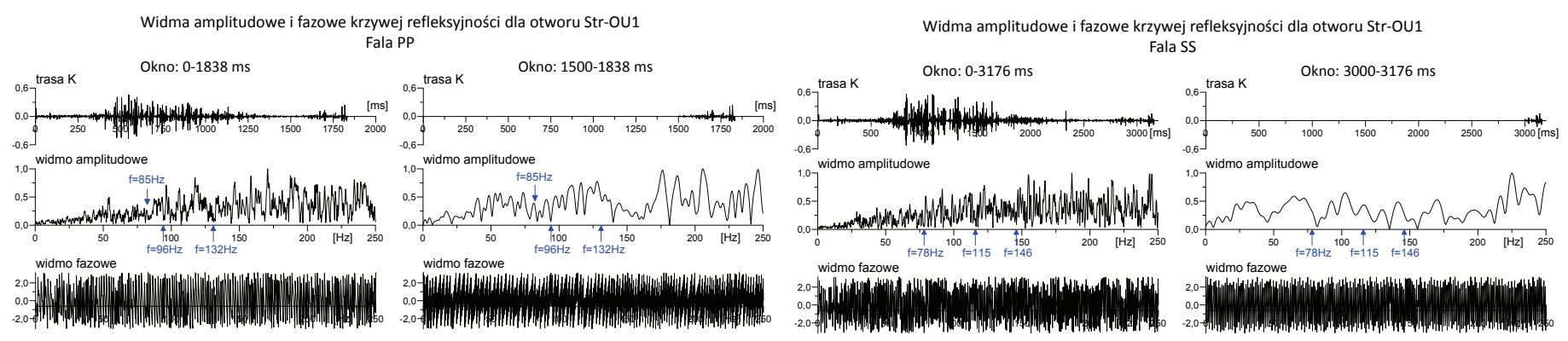

Rys. 14b. Krzywe refleksyjności fal PP i SS i odpowiadające im spektra kompleksowe.

Zakres widma efektywnego fali P wynosi około $50 \div 132 \mathrm{~Hz}$, dla fali S około $70 \div 146 \mathrm{~Hz}$

geologicznego, szczególnie o budowie geometrycznie skomplikowanej i o małej lub bardzo małej miąższości warstw lub wydzieleń litologiczno-facjalnych, jest oczywisty. Propagująca fala sejsmiczna na skutek oddziaływania z ośrodkiem oraz w zależności od rodzaju kanału transmisji najczęściej częściowo traci właściwości występujące w punkcie wzbudzenia (m.in. amplituda, długość fali), a więc częstotliwości konieczne do przekazania poprawnej odpowiedzi ośrodka.

Na rysunku 15a i b przedstawiono zestawienia wyników analizy zespolonych charakterystyk spektralnych tras syntetycznych oraz rzeczywistych w zakresie $0 \div 1838 \mathrm{~ms}$ (fala P) oraz $0 \div 3176$ ms (fala $S$ ).

Natomiast z rysunku 16 można wnioskować, że kształt widma trasy sumarycznej sugeruje, iż zakres częstotliwości niezbędnych do odtworzenia ośrodka nie przekracza $100 \mathrm{~Hz}$.

Takie techniki przetwarzania zapisu sejsmicznego jak filtracja czy dekonwolucja posługują się wyłącznie informacjami, które „widzi” trasa sejsmiczna. Sądzić więc należy, że użycie dodatkowej informacji, której dostarczają dane otworowe, jest propozycją uzasadnioną. Powyższe zostało wykorzystane w realizacji zadania pt.: Poszukiwanie, rozpoznawanie - modelowanie i przetwarzanie danych sejsmicznych, w tym metodyka określania żądanej rozdzielczości sejsmicznego pola falowego w procesie lokalizacji, udostepniania i eksploatacji formacji łupkowych, jako jednego z zadań projektu GASŁUPSEJSM w programie Blue Gaz - Polski Gaz Łupkowy pt.: Badania sejsmiczne i ich zastosowanie dla detekcji stref występowania gazu z lupków. Dobór optymalnych parametrów akwizycji i przetwarzania w celu odwzorowania budowy strukturalnej oraz rozkładu parametrów petrofizycznych i geomechanicznych skat perspektywicznych.

Jak wspomniano we wcześniejszych publikacjach z tego cyklu, propozycja ta znalazła wyraz algorytmiczny i programowy. Została również opatentowana - w roku 2014 w Polsce i 2017 w USA. Aktualnie przygotowana została dokumentacja patentowa uwzględniająca parametry fali poprzecznej rejestrowanej w otworze.

W niniejszej publikacji w dalszej kolejności pokazano opcję wykorzystania fali podłużnej w konstrukcji operatora modyfikacji spektralnej oraz ocenę uzyskanych wyników w kontekście możliwości zwiększenia rozdzielczości, które niesie zwiększenie krotności sumowania.

Na rysunku 17 przedstawiono określone operatory modyfikacji w różnych opcjach, zależnych od przyjętych założeń, 
Widma amplitudowe i fazowe dla splotu Rc z sygnałem Rickera 20, 50, 70, $125 \mathrm{~Hz}$ i ich suma Otwór Str-OU1; fala PP; okno: 0-1838 ms
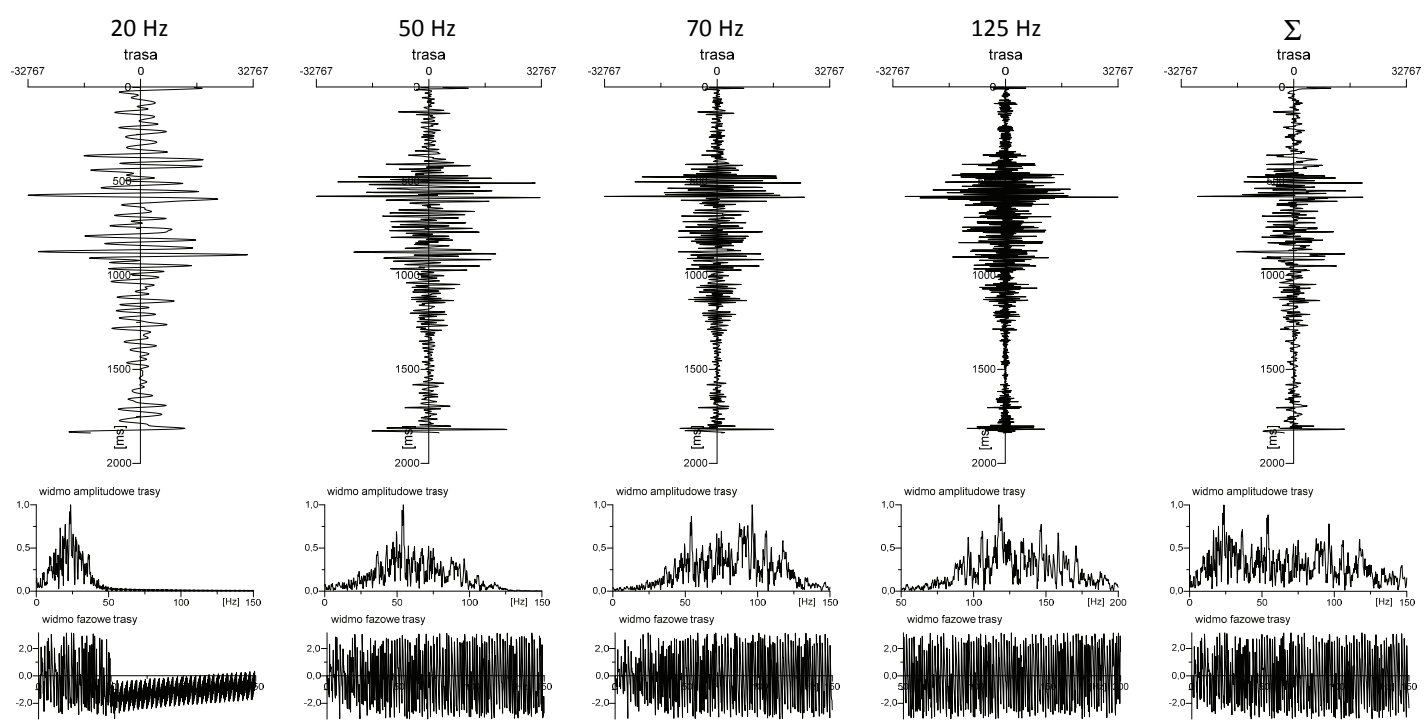

Widma średniej FA z okna 0-1838 ms, trasy 1-10, fala PP

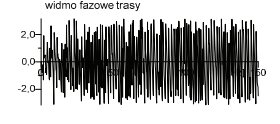
Splot Rc z sygnałem Ricker

(a)
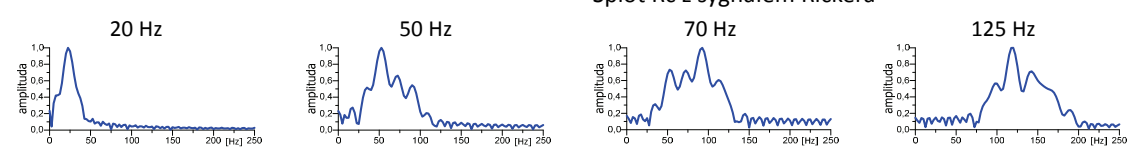

Suma splotów Rc

z sygnałem Rickera

$20,50,70$ i $125 \mathrm{~Hz}$

Widma amplitudowe i fazowe dla splotu Rc z sygnałem Rickera 20, 50, 70, $125 \mathrm{~Hz}$ i ich suma Otwór Str-OU1; fala SS; okno: 0-3176 ms
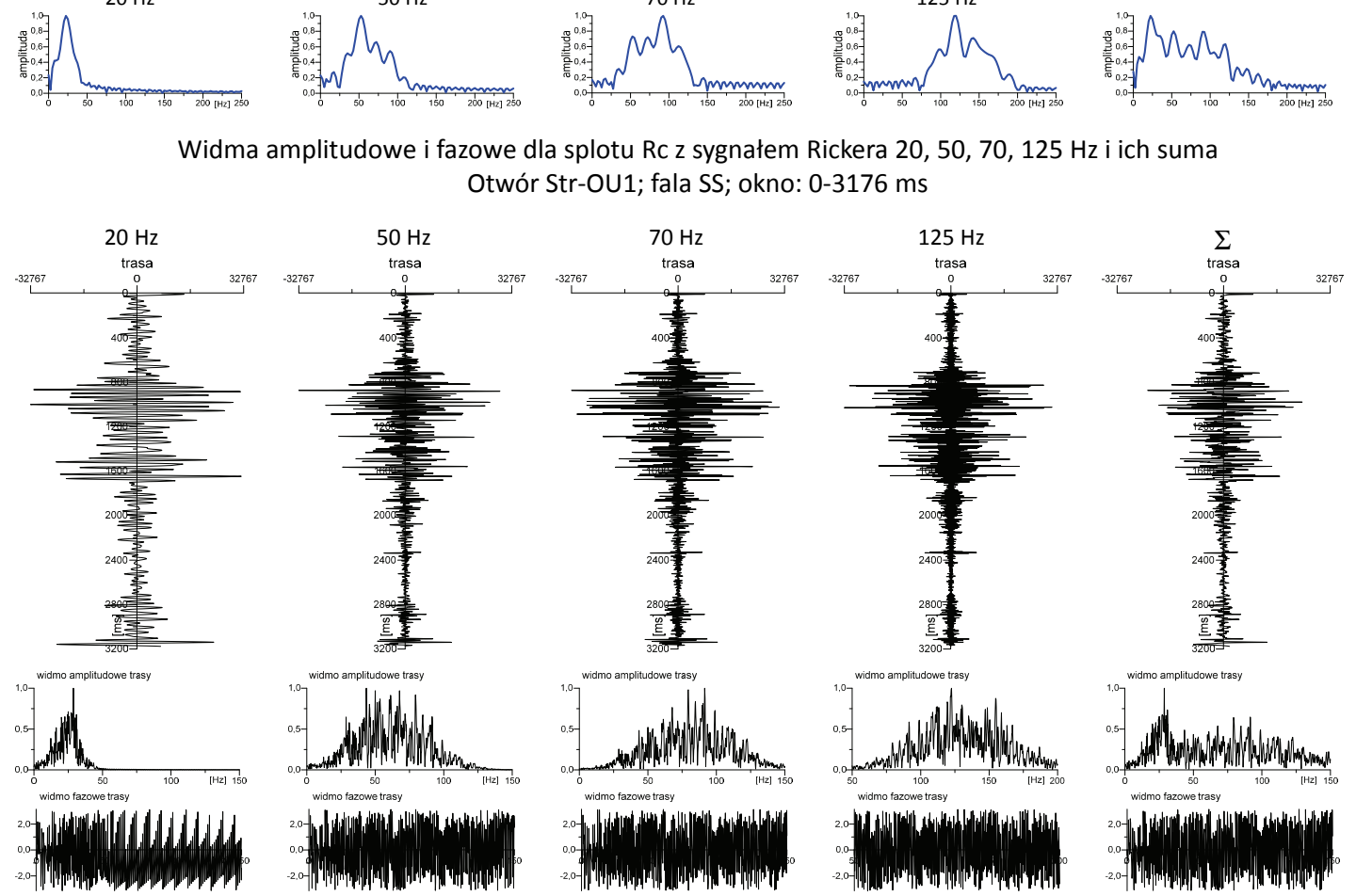

Widma średniej FA z okna 0-3176 ms, trasy 1-10, fala SS Splot Rc z sygnałem Rickera

(b)
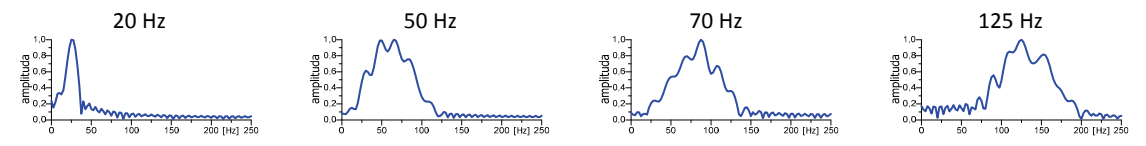

Suma splotów Rc z sygnałem Rickera 20, 50, 70 i $125 \mathrm{~Hz}$

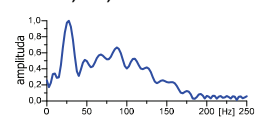

Rys. 15. Porównanie charakterystyk spektralnych tras syntetycznych i rzeczywistych fal podłużnych (a) i poprzecznych (b)

dotyczących informacji z danych powierzchniowych i otwo- - wyłącznie z danych otworowych (a), rowych, uwzględniając szczególnie rolę charakterystyki fazo- • wyłącznie z danych sejsmicznych (b), wej. W analizowanym przypadku założono, że widmo ampli- • • zarówno z danych otworowych, jak i sejsmicznych (c), tudowe jest określone $\mathrm{z}$ danych sejsmicznych i otworowych, • oraz poprzez narzucenie zerowej wartości widma fazowenatomiast widmo fazowe kolejno: go dla całego przedziału częstotliwości (d). 
Widma amplitudowe i fazowe dla splotu Rc oraz odpowiadające im widma średniej FA Otwór Str-OU1; fala PP; okno: 0-1838 ms
Widma amplitudowe i fazowe dla splotu Rc oraz odpowiadające im widma średniej FA Otwór Str-OU1; fala SS; okno: 0-3176 ms

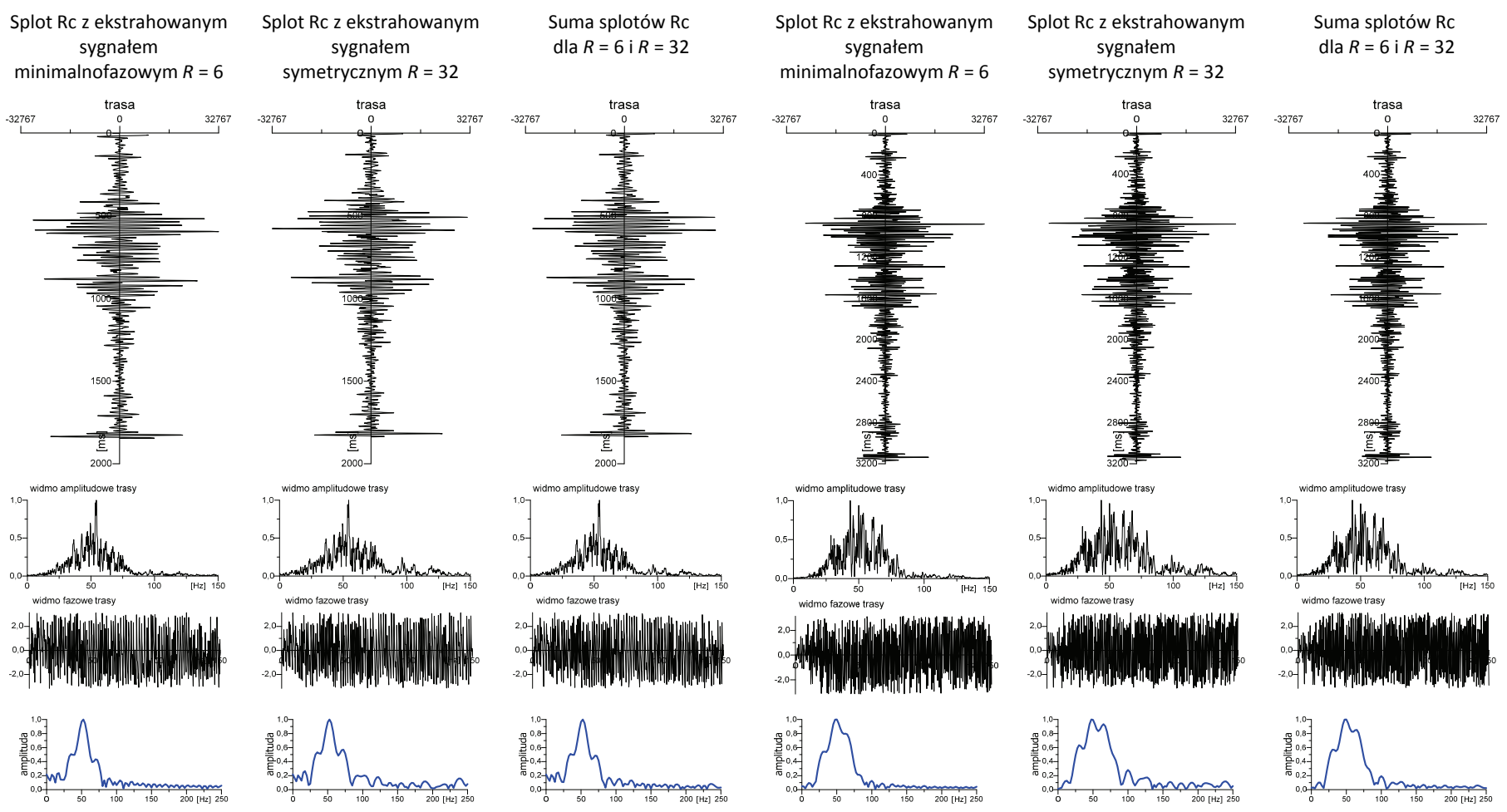

Rys. 16. Wykorzystanie sygnałów ekstrahowanych z danych rzeczywistych do analizy widma amplitudowego

Otwór: Str-OU1
Fala: PP; dt:2 ms

Poziom odniesienia: $100.00 \mathrm{~m}$ n.p.m.

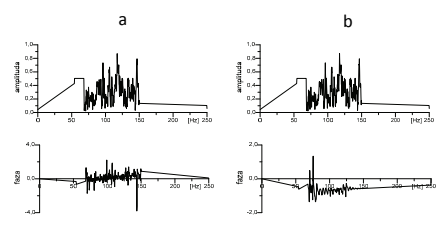

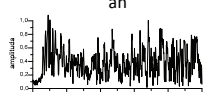
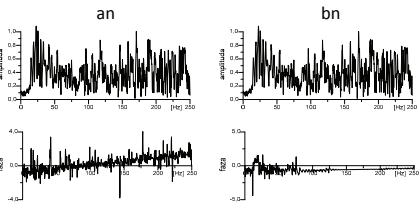

$\varphi z$ otw.

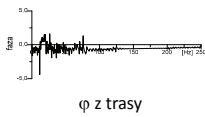

$\varphi$ z trasy

Studium wpływu fazy idma operatorów modyfikacji
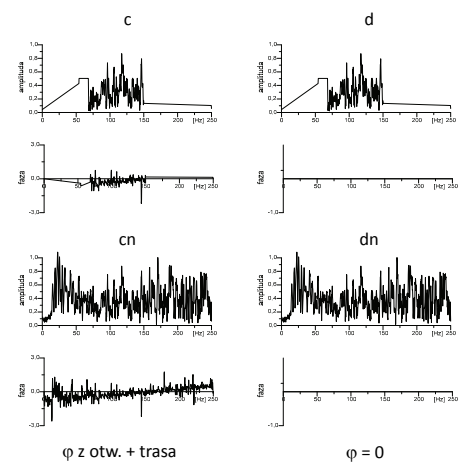

Otwór: Str-OU1
Fala: PP; dt: 2 ms Poziom odniesienia: $100.00 \mathrm{~m}$ n.p.m.

Widma operatorów modyfikacji ab, abm, abn, ac, acm, acn (predope2)

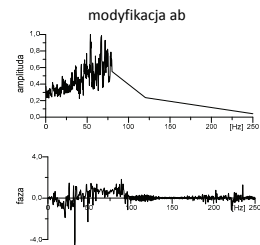

modyfikacja ac
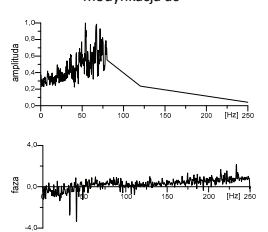

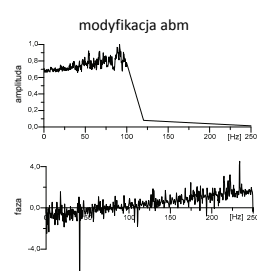

modyfikacja acm
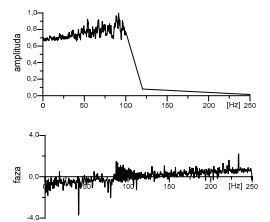

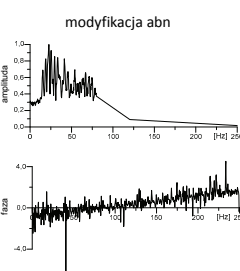

modyfikacja ac
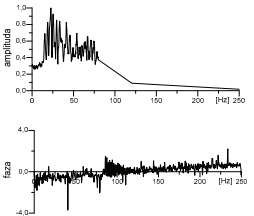

Rys. 17. Zestawienie operatorów modyfikacji spektralnej obliczonych na danych sejsmicznych projektu 3D (koncesja Wierzbica) w zależności od sposobu wprowadzenia fazowej charakterystyki spektralnej (część lewa) oraz od zakresu wprowadzonych wysokich częstotliwości (część prawa)

Kolejnym etapem realizacji procedury zwiększania rozdzielczości było zaaplikowanie określonych operatorów na danych sejsmicznych w projekcie Wierzbica 3D. Zgodnie z projektem akwizycję przedstawił, jak wcześniej wspomniano, zespół Katedry Surowców Energetycznych WGGiOŚ AGH. Wyniki tych aplikowań dla wariantów W3 (krotność 469) i W1 (krotność 2670) zaprezentowano na rysunkach 18 i 19, natomiast sygnały wyekstrahowane $\mathrm{z}$ kolejnych przetworzeń na rysunkach 20 (a, b) i 21 (a, b). Łatwo zauważyć, że efekty mo- dyfikacji znacznie łatwiej wyodrębnić w domenie spektralnej (rysunek 19) niż w czasowej (rysunek 20).

Bardziej spektakularne i standardowo uzyskane wyniki zostaną przedstawione na fragmentach sekcji sejsmicznych $w$ interwale celu geologicznego, na przykładzie horyzontu $\mathrm{S}_{\mathrm{ld}}, \mathrm{S}_{\mathrm{w}}$ i O.

Na rysunku 20 pokazano wyniki zaaplikowania operatorów modyfikacji zróżnicowanych tylko w zakresie widma fazowego, testowanych na profilu XL270 w przedziale utworów 
Wariant 3

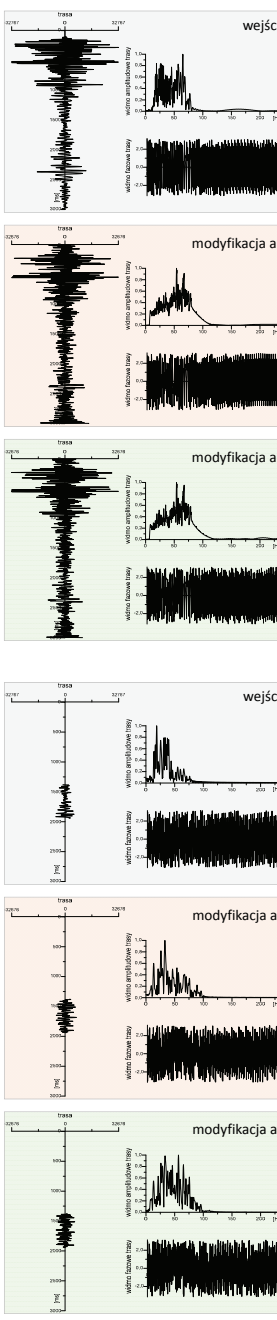
Trasa: IL143 Okno: 0-2998 ms Trasa: IL143

Okno: $1380-1940 \mathrm{~m}$
Widma amplitudowe i fazowe

Profil: XL270_W3_after po modyfikacji: ab, abm, abn, ac, acm, acn
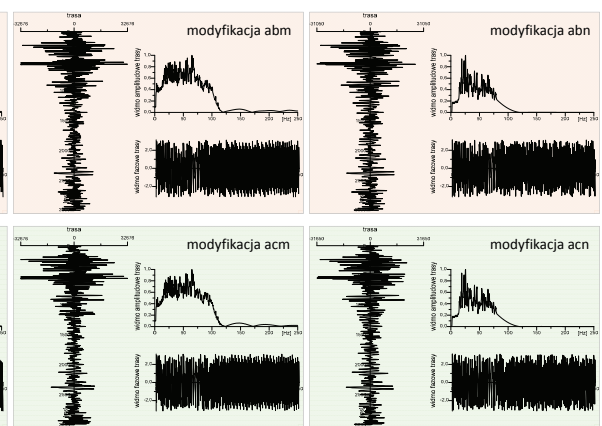

Widma amplitudowe i fazowe

Profil: XL270_W3_after po modyfikacji: ab, abm, abn, ac, acm, acn
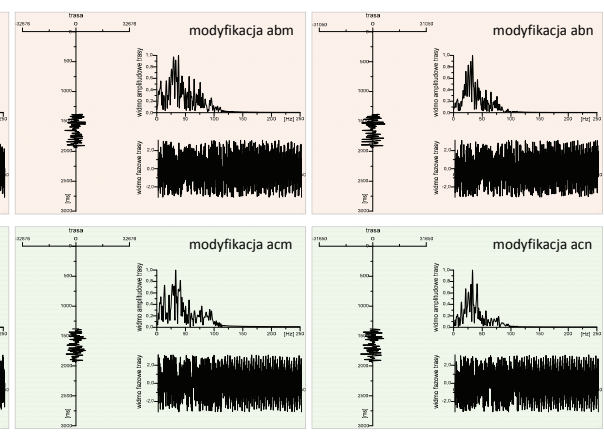

Rys. 18. Wyniki modyfikacji spektralnej danych sejsmicznych. Profil XL270, wariant W3 i W1 - po modyfikacji spektralnej ab, abm, abn, ac, acm, acn
Wariant 1
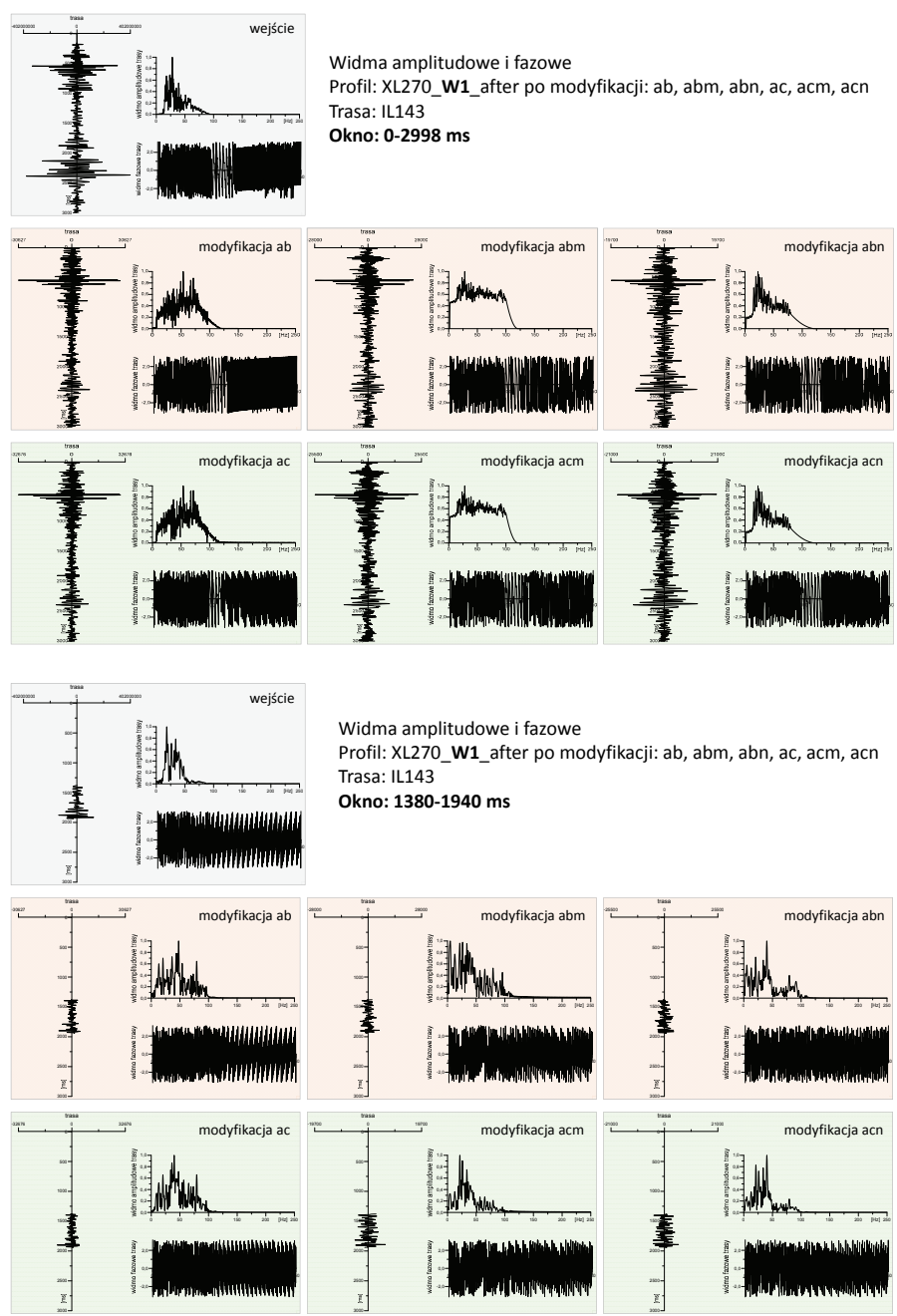

sylurskich, a szczególnie $\mathrm{S}_{\mathrm{ld}}(2 \mathrm{~T} \cong 1740 \mathrm{~ms}), \mathrm{S}_{\mathrm{w}}(2 \mathrm{~T} \cong 1842 \mathrm{~ms})$ $\mathrm{i} \mathrm{O}_{2}(2 \mathrm{~T} \cong 1930 \mathrm{~ms})$.

Na obrazie falowym zauważa się różnice zarówno w usytuowaniu refleksów, jak i w ich dynamice. Analiza tych faktów została przedstawiona poniżej poprzez szczegółowe odniesienie do danych otworowych (w ramach testów wykonanych przez zespół WGGiOŚ AGH).

Pomimo że niniejsza publikacja nie jest poświęcona interpretacji, a tylko wskazaniu nowych możliwości opracowanej metodyki, zwrócić należy uwagę, że różne wersje obrazu falowego (an, bn, cn, dn) wnoszą nowe, być może bardzo cenne informacje, którym doświadczony interpretator-geolog może i powinien nadać sens geologiczny. Przedstawione obliczenia wykonano dla wariantu 3 (W3) danych sejsmiki 3D, dla którego krotność sumowania wynosi 469.

W świetle zamysłu twórców projektu (AGH) jest to wariant, który dostarcza informacji o niższej rozdzielczości niż wariant 1 (W1), dla którego krotność sumowania wynosi 2270. Powyższą prawidłowość prześledzono na rysunku $21 \mathrm{w}$ in- terwale $1380 \div 2180 \mathrm{~ms}$. Począwszy od danych INPUT (lewa strona W1, prawa W3), horyzont sylurski jest dość słabo odtworzony na polu falowym, dopiero strop ordowiku jest odwzorowany refleksem - bardziej wyraźnym w wariancie 1.

Analizując przedstawione na rysunku 21 wyniki po zaaplikowaniu różnych operatorów modyfikacji, zauważa się, że najlepsze odtworzenie refleksu $\mathrm{S}_{\mathrm{w}}$ uzyskuje się przy zastosowaniu operatora w opcji a (silny udział charakterystyki fazowej z otworu). Dotyczy to zarówno wariantu 1, jak i wariantu 3; czytelniejszy układ refleksu obserwuje się w wariancie 3, co pozwala na sformułowanie wniosku, że modyfikacja spektralna umożliwia podniesienie rozdzielczości sekcji na poziomie przetwarzania, co jest nieporównanie mniej kosztochłonne niż stosowanie skomplikowanych schematów akwizycji. Natomiast horyzont $\mathrm{S}_{\mathrm{ld}}$ jest wyraźnie lepiej odtworzony poprzez modyfikację abn w wariancie 1, a strop ordowiku - poprzez modyfikację am3 (znaczne rozszerzenie w stronę wysokich częstotliwości), nawet już w wariancie 3. Zjawisko właściwie oczywiste - wraz ze zwiększającą 

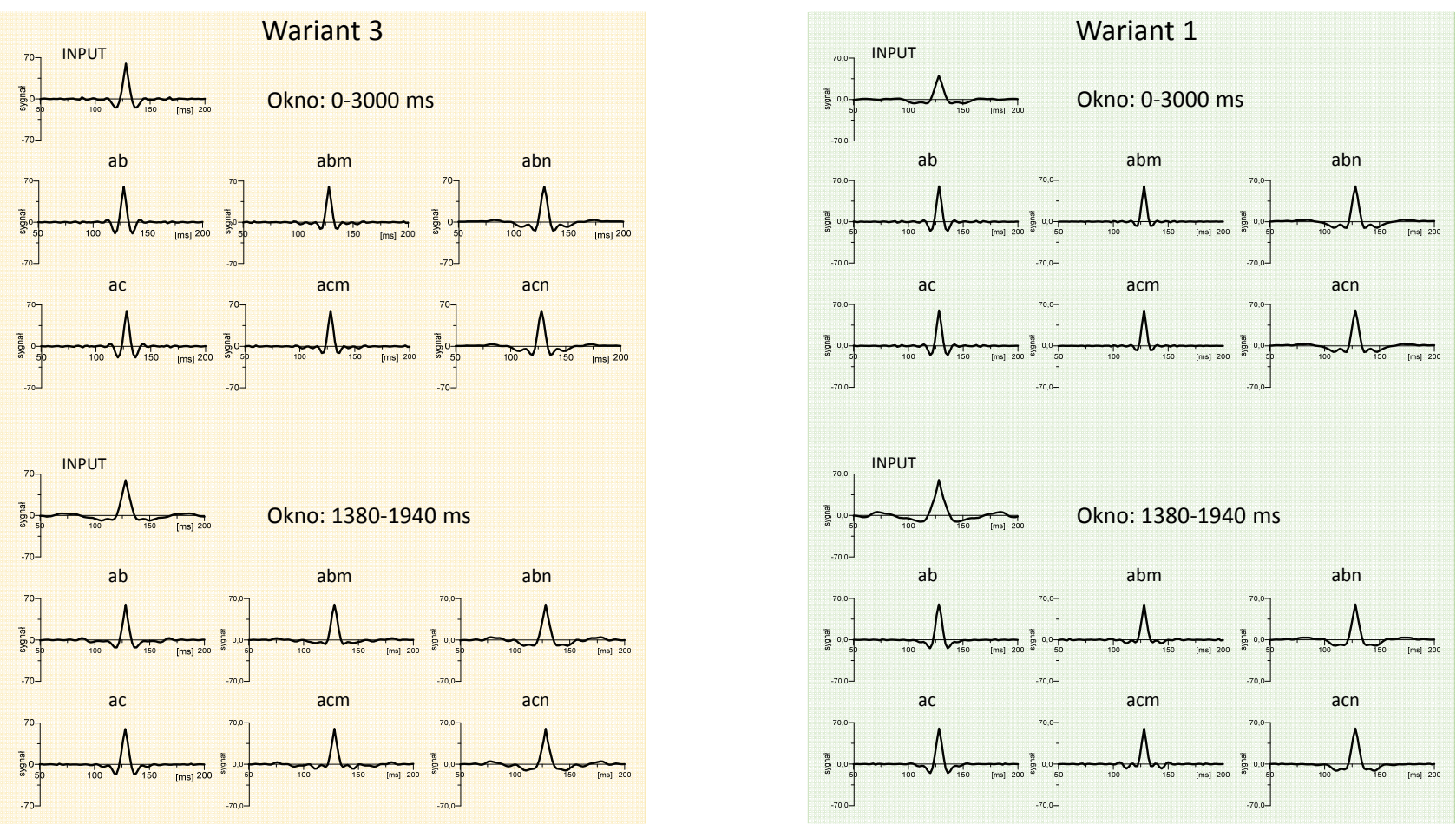

Rys. 19. Porównanie sygnałów wyekstrahowanych z sekcji wejściowej (migration AFTER STACK) oraz po różnych opcjach modyfikacji spektralnej, uwzględniających szczególnie zakres niskich częstotliwości (abn, acn), jak i poszerzających zakres częstotliwości do $120 \mathrm{~Hz}$ (abm, acm); wariant W3 (a), wariant W1 (b)

się głębokością horyzontu dochodzi do większego pochłaniania wysokich częstotliwości.

Syntetyczne przedstawienie wyników dla wariantu 1 pokazano na rysunku $22(a, b)$, gdzie widzimy porównanie kostek 3D danych INPUT i po wybranych modyfikacjach (a, acn) dla wzajemnie prostopadłych profili XL260 oraz IL140.

Obraz pola falowego na danych INPUT prezentowany w płaszczyźnie $\{\mathrm{X}, 2 \mathrm{~T}\}$ jest wyraźnie lepszy na profilu XL260, zwłaszcza w interwale sylurskim; natomiast zaaplikowanie modyfikacji, szczególnie w opcji operatora acn, upodabnia wzajemnie obydwa wyniki XL260 i IL140, co świadczy o przydatności procedury modyfikacji spektralnej, w tym konkretnym przypadku, do optymalizacji obrazu w domenie czasowej.

Analogicznie porównujemy wyżej omówione wyniki w konwencji 3D - rysunek 23, dla wzajemnie prostopadłych profili IL140 oraz XL260. Modyfikacja spektralna w pewnym stopniu niweluje różnice w obrazie pola falowego, spowodowane mniej (W3) lub bardziej (W1) zaawansowaną akwizycją. Szczególnie dotyczy to, praktycznie „bezrefleksowego" na danych wejściowych

dane wejściowe

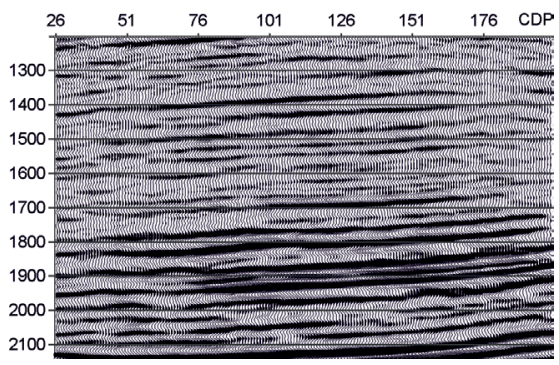

$\mathrm{z}$ danych otworowych
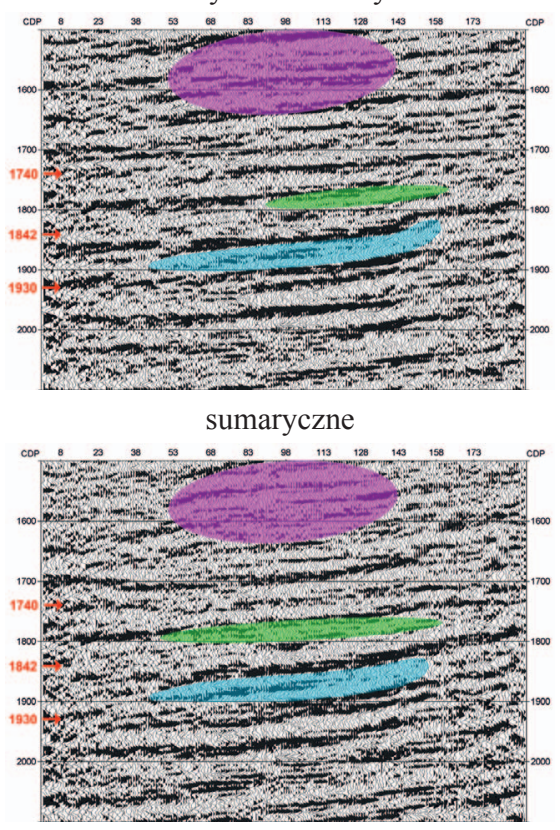

Rys. 20. Porównanie wyników modyfikacji spektralnej danych wejściowych dla różnych opcji charakterystyki fazowej operatora modyfikacji 

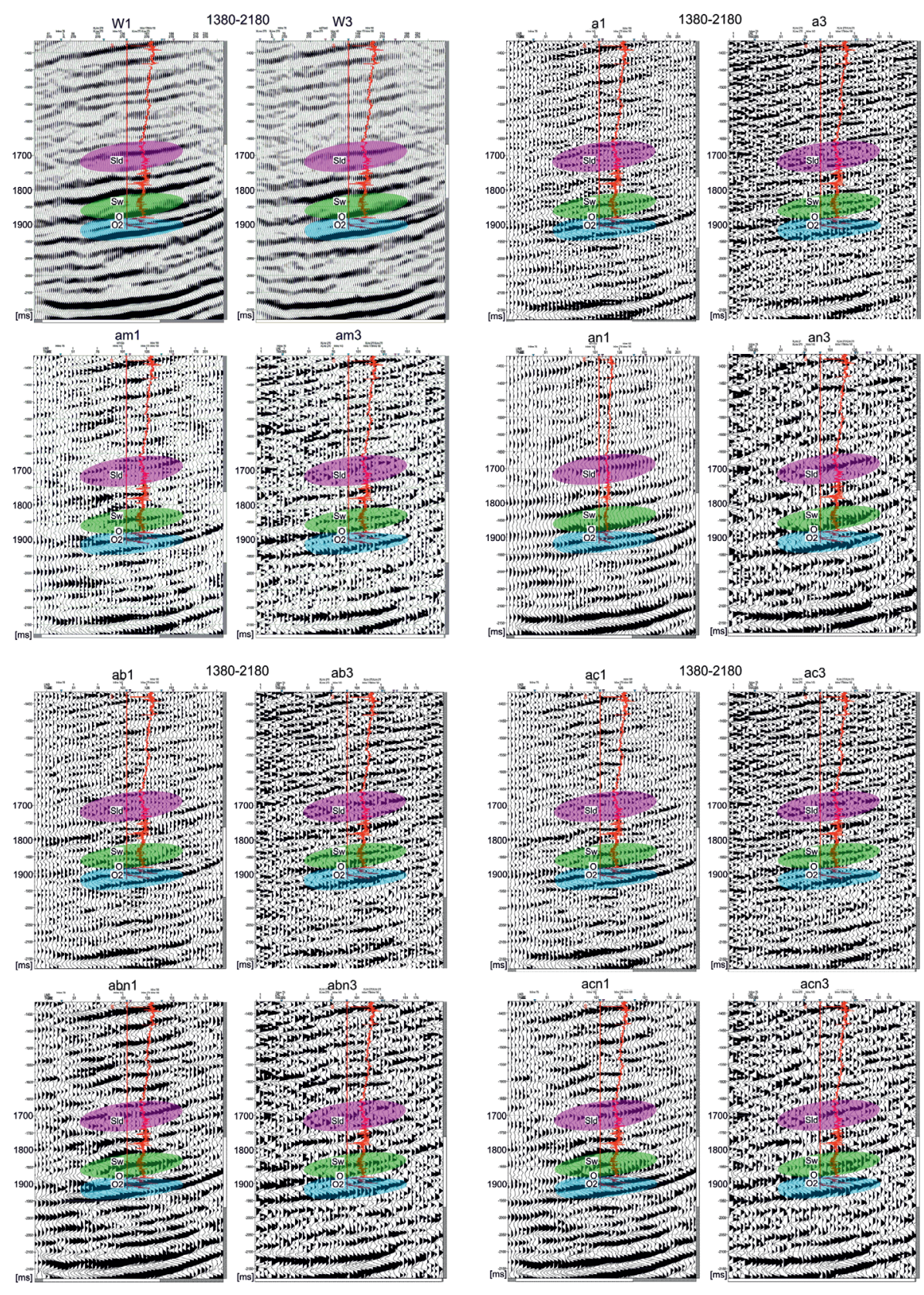

acn3
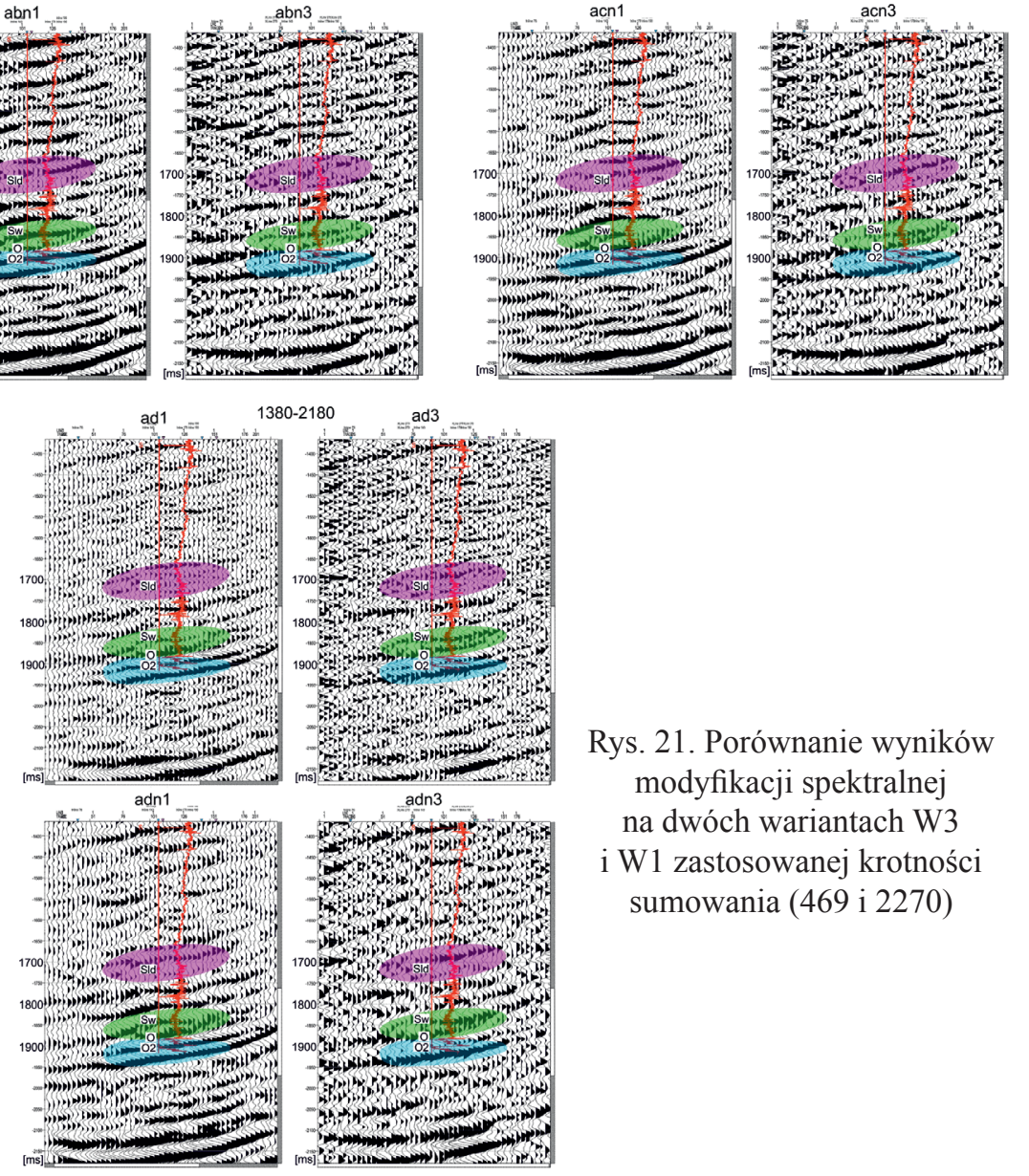

(migration AFTER STACK), interwału sylurskiego.

Niemniej już na podstawie przeprowadzonych eksperymentów obliczeniowych można mniemać, że opracowanie tzw. recepty dla danej klasy ośrodków może być bardziej kłopotliwe niż przeprowadzenie kilku testów, które umożliwiają określenie operatora modyfikacji z dość dużą dokładnością i ukierunkowaniem na potrzeby w zakresie charakterystyki spektralnej danego obiektu.

Na rysunku $24(a, b)$ zaprezentowano cykl obliczeń według procedury modyfikacji spektralnej w oknie 1380 $\div 1940 \mathrm{~ms}$, odpowiadającym formacji sylurskiej, dla wariantów W3 i W1 i opcji operatora a i acn.

Charakterystyczną obserwacją jest zróżnicowanie obrazu spektralnego, natomiast niewielkie zróżnicowanie wyekstrahowanych sygnałów, co przemawia za sprawniejszą oceną obrazu falowego w domenie spektralnej. Ponadto charakterystyki spektralne tras wejściowych dla wariantów W3 i W1 są bardzo podobne; częstotliwość dominująca okoto $32 \mathrm{~Hz}$ w wariancie W1 silniej wygasza amplitudy dla częstotliwości w zakresie 50 $\div 70 \mathrm{~Hz}$. Zróżnicowane modyfikacje (a, acn) różnie oddziałują na kształt widma wynikowego w wariantach W1 i W3.

Jednym z najbardziej wiarygodnych dowodów poprawności przetworzenia i interpretacji sekcji sejsmicznych jest przedstawienie sekcji impedancji i prędkości sejsmicznych obliczonych drogą inwersji sejsmicznej i porównanie ich z wynikami profilowania prędkości w otworze. Na rysunku $25(\mathrm{a}, \mathrm{b})$ porównano sekcje impedancji akustycznej w wersjach INPUT i o znacznie podwyższonej częstotliwości W3_dn i W1_dn. Zaaplikowanie opcji operatora $\mathbf{d n}$ na wariancie 1 , gdzie już sama krotność sumowania 2670 wnosi poszerzenie częstotliwości, nie poprawia rozdzielczości, wręcz odwrotnie, najprawdopodobniej dodawane są artefakty wynikające $\mathrm{z}$ interferencji niezidentyfikowanych częstotliwości, co może sugerować kształt widma. 


\section{NAFTA-GAZ}

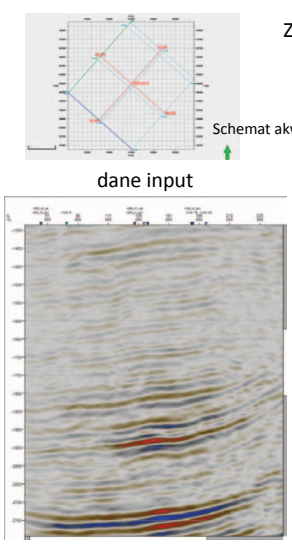

Zestawienie wyników zwiększenia rozdzielczości sekcji sejsmicznych

(koncesja Wierzbica 3D; profil XL260)
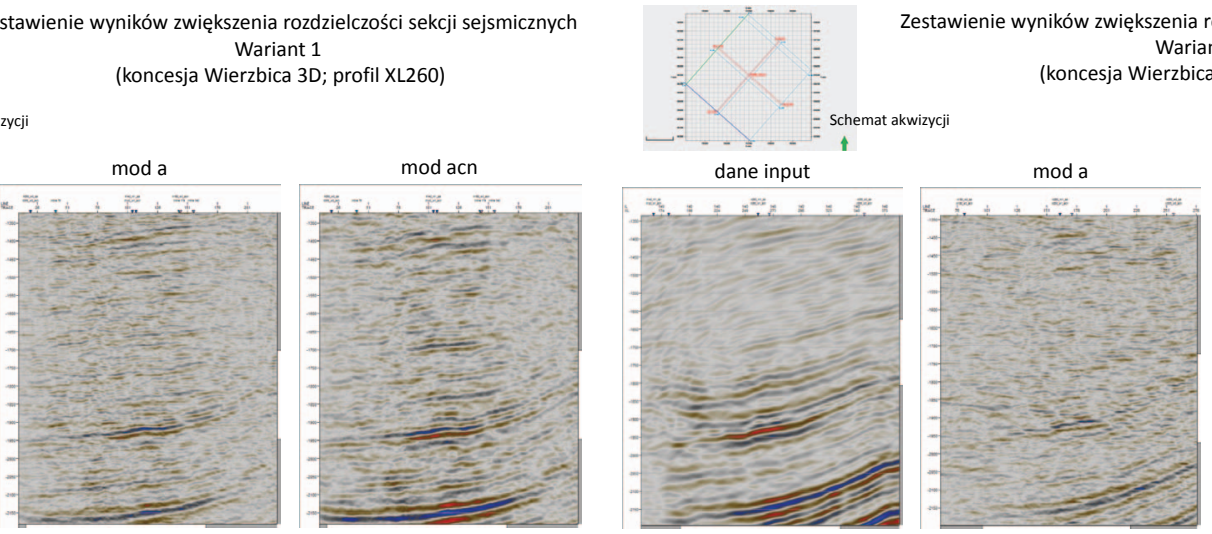

Wariant

1

Rys. 22. Wyniki zaaplikowania procedury modyfikacji spektralnej w zależności od kierunku rejestracji danych sejsmicznych (profile XL260, IL140)
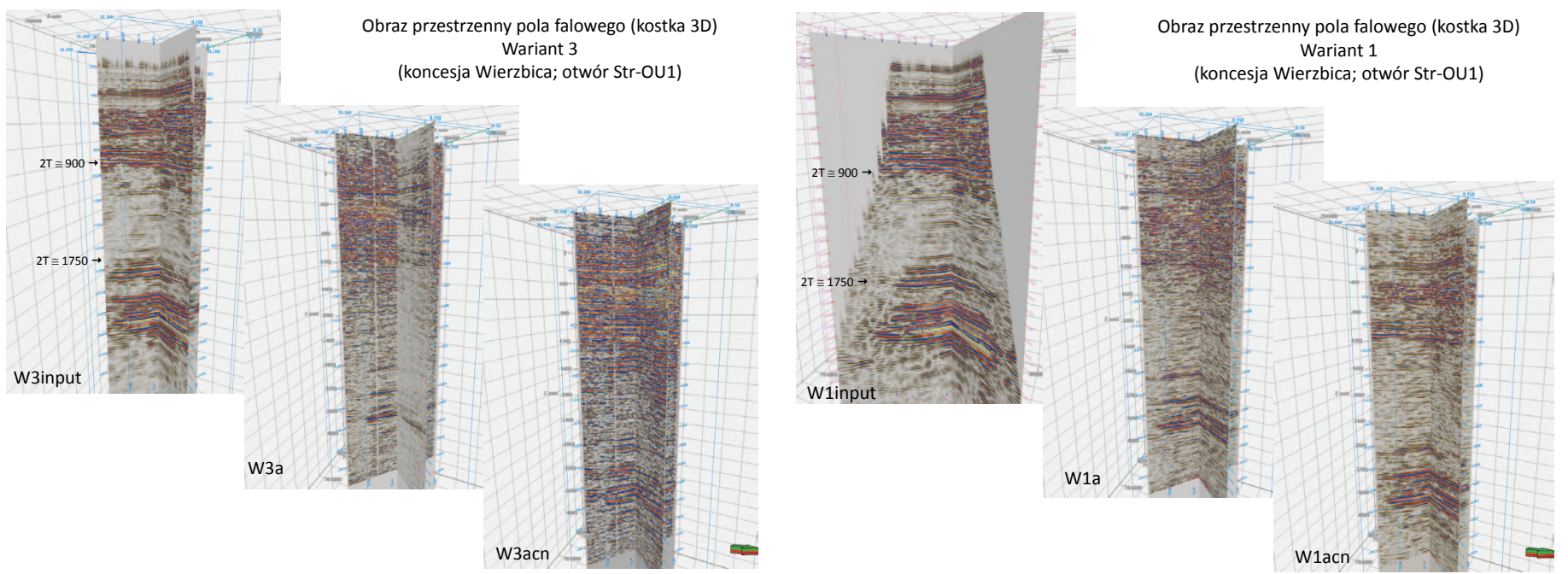

Rys. 23. Porównanie obrazu falowego dla wariantu 3 i wariantu 1

Widma średniej FA, widma amplitudowe i fazowe, widma operatorów modyfikacji, sygnały z FA $(R=64)$ Profil: XL270_W3_after po modyfikacji a, acn; Okno: $\mathbf{1 3 8 0 - 1 9 4 0 ~ m s ~}$

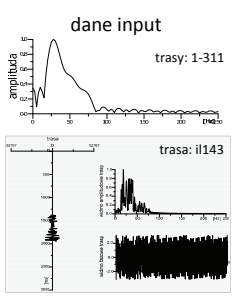

Cykl obliczeń dla W3 okno $1380-1940$

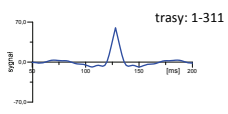

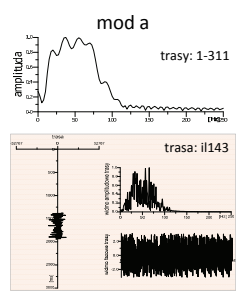
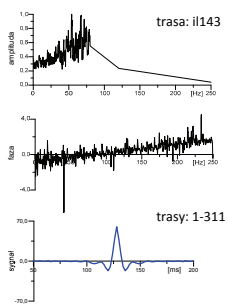
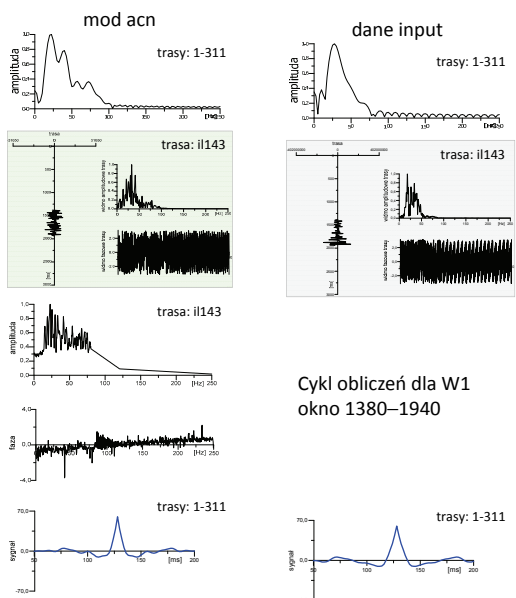

Widma średniej FA, widma amplitudowe i fazowe, widma operatorów modyfikacji, sygnały z FA ( $R=64)$ Profil: XL270 W1 after po modyfikacji a, acn; Okno: 1380-1940 ms
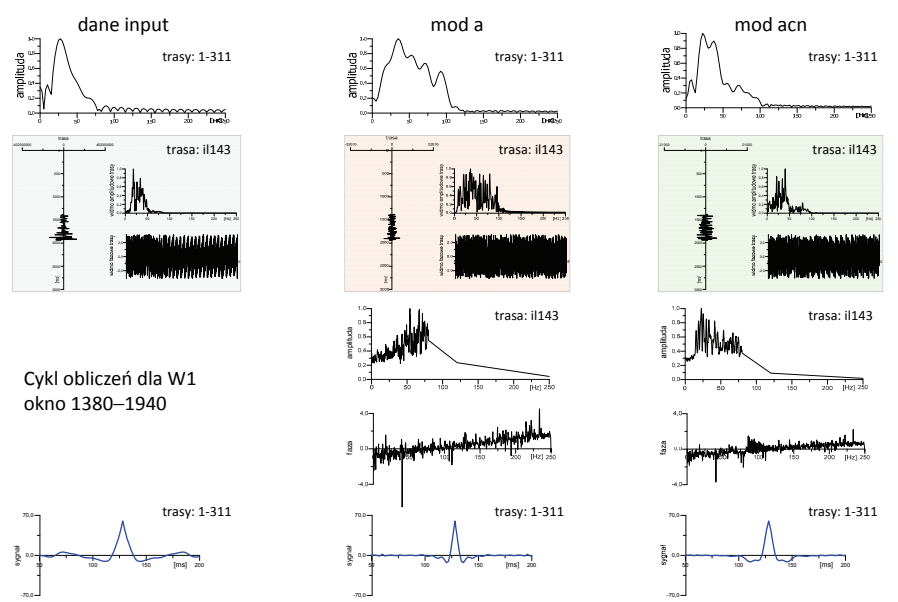

Rys. 24. Porównanie wyników modyfikacji a i acn na danych wariantów W3 i W1
Nadmierne poszerzenie zakresu częstotliwości negatywnie oddziałuje na obraz impedancji akustycznej. Sprawdzenie tego faktu zostało dokonane przez J. Barmutę i P. Łapinkiewicza z zespołem realizatorów AGH.
Testowanie przedstawionego w niniejszym artykule przez autora i zespół (K. Żukowska oraz I. Irlik) rozwiązania prowadzono, wykorzystując system Petrel oraz profesjonalne procedury i programy komercyjne zespołu AGH, co z pewnością skutkuje 
doskonałą szatą graficzną. Natomiast wszystkie prezentowane w niniejszej publikacji rysunki zostały wykonane na podstawie autorskiego oprogramowania tworzonego na przestrzeni kilkunastu lat w Zakładzie Sejsmiki Instytutu Nafty i Gazu - PIB, którego głównymi autorami są Krystyna Żukowska i Krzysztof Żuławiński.

Podsumowując wyniki testów, odwołajmy się do przedstawionych rysunków, punktujących takie elementy rozwiązania, które budzą zastrzeżenia z punktu widzenia pełnej poprawności obrazu falowego.

I tak na rysunku 26 (a, b) zaprezentowano wyniki analizy spektralnej dla sygnałów wyekstrahowanych z danych sejsmicznych - w interwale sylursko-ordowickim $1400 \div 1920 \mathrm{~ms}$ - w wariancie W3 po modyfikacji w opcji a oraz $\mathrm{z}$ danych w wariancie W1 po modyfikacji w opcji an.

Pole falowe w wariancie W3 poddano modyfikacji z aplikacją a, wnoszącą wysokie częstotliwości w zakresie $70 \div 150 \mathrm{~Hz}$, co odzwierciedlone jest w spektrum amplitudowym; jednocześnie zauważa się szeroko rozbudowany, prawie dwumodalny sygnał, jednak jego część centralna skupiona jest w czasie $25 \mathrm{~ms}$.

Pole falowe w wariancie W1 poddano modyfikacji według aplikacji an, przesuwającej częstotliwość dominującą w stronę niskich częstotliwości w zakresie $60 \div 80 \mathrm{~Hz}$. Uzyskano sygnał znacznie mniej rozbudowany, z obwiednią prawie symetryczną.

Nadmierne rozbudowanie sygnału można zaliczyć do efektów negatywnych modyfikacji spektralnej, nawet pomijając fakt, że efekt ten można likwidować, np. poprzez stosowanie dekonwolucji.

Należy tutaj wspomnieć, że w opinii autora dążenie poprzez procedury przetwarzania do sygnału o charakterystyce typu SPIKE utożsamić często można z usuwaniem cennych informacji geologicznych dotyczących obiektu poszukiwań. Sygnał szpilkowy i jego FFT ${ }^{-1}$ odwrotność w postaci płaskiego szerokiego widma nie dorównują informacjom szerokiego spektrum. Odnośnie do ewoluowania poglądów na temat użyteczności rozmaitych składowych pola falowego należy przywołać ekscytujący artykuł A.J. Berkhouta, opublikowany w „Geophysical Prospecting”, którego tytuł warto przytoczyć: Utilization of multiple scattering: the next big step forward in seismic imaging [1], w którym autor

W3_input
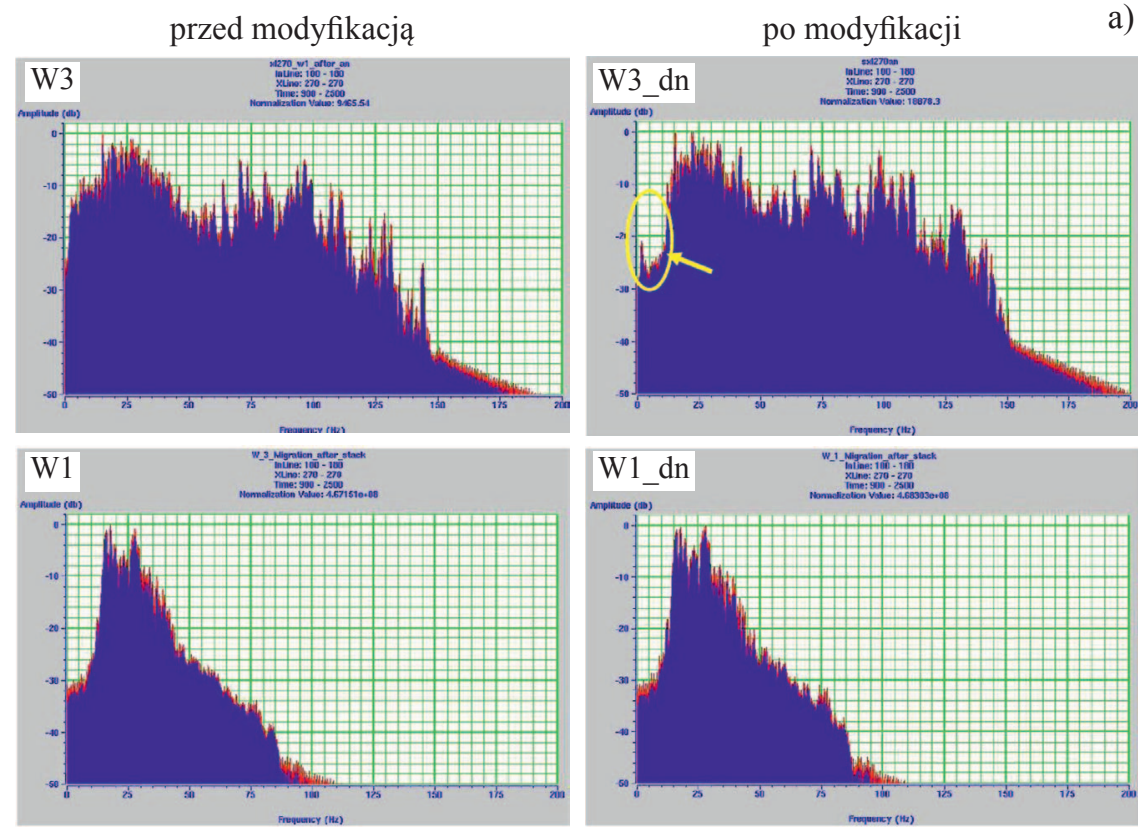

przed modyfikacją

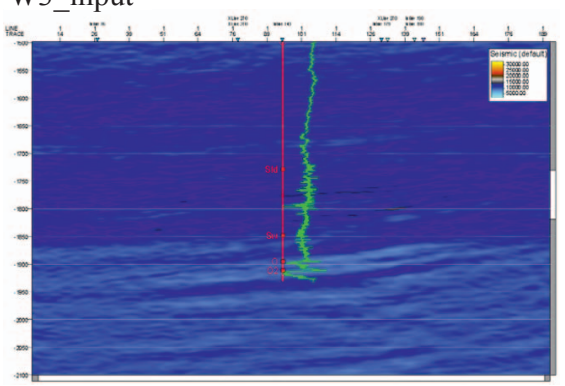

po modyfikacji

b)

W3_dn
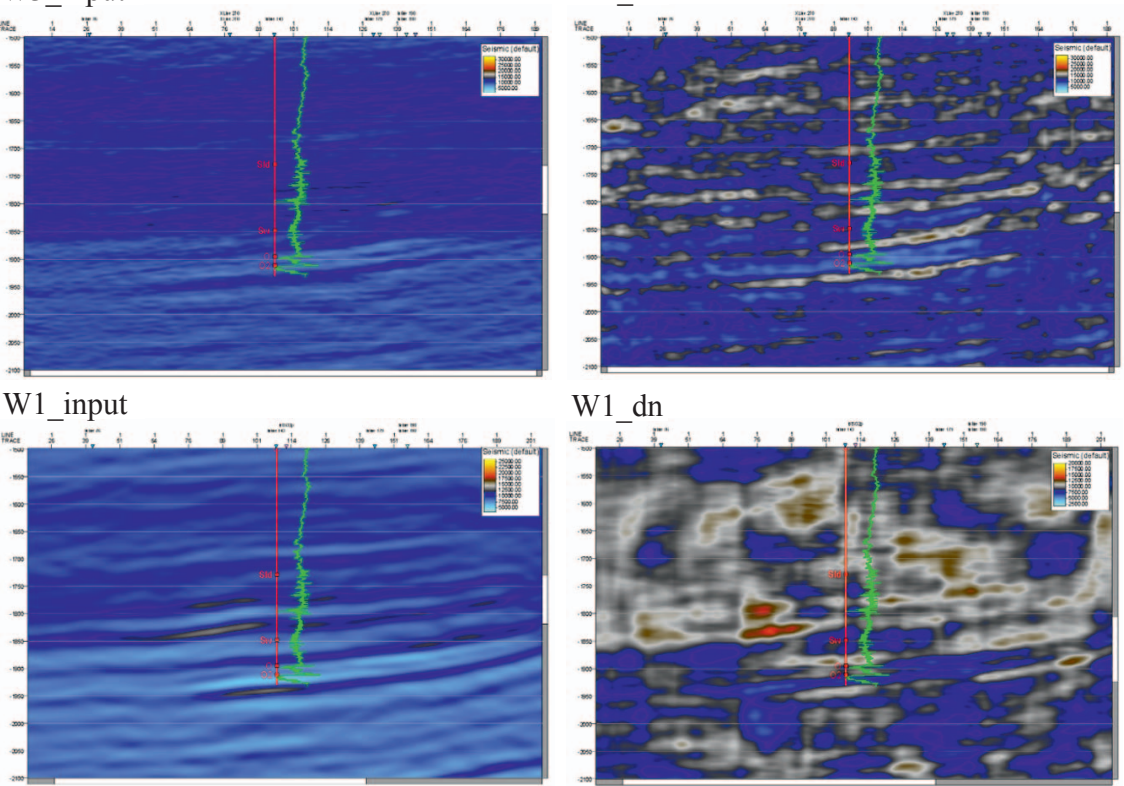

W1_dn

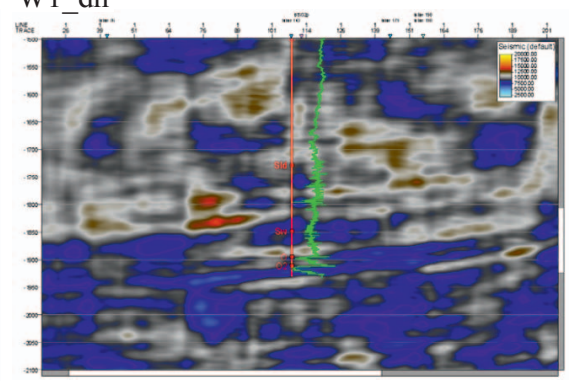

Rys. 25. Wyniki zwiększania rozdzielczości. Widma amplitudowe danych wejściowych i po modyfikacji w opcji dn (obustronne poszerzenie zakresu częstotliwości) (a) i wyniki obliczenia IA na sekcji sejsmicznej przed i po modyfikacji charakterystyki spektralnej (b)

przedstawia sposób wykorzystania odbić wielokrotnych jako ważne źródło wiedzy o ośrodku.

Warto nadmienić, że podobny problem, niestety na znacznie niższym poziomie w zakresie dowodów matematycznych, był realizowany przez autorkę w latach 1995-1998 na zlecenie Geofizyki Toruń. Pomysł nie wyszedł poza obszar marzeń lub raczej mrzonek.

Pomimo powyższych „nawiązań”, uwagi dotyczące kształtu sygnału, wynikające $\mathrm{z}$ analizy zespołu AGH, na obecnym etapie rozpoznania zagadnienia należy uznać za słuszne. 
Przykładowy sygnał ekstrahowany w oparciu o otwór (metoda deterministyczna) (W3_a) - szerokie „side loby”
Przykładowy sygnał ekstrahowany w oparciu o otwór (metoda deterministyczna) (W1_an)

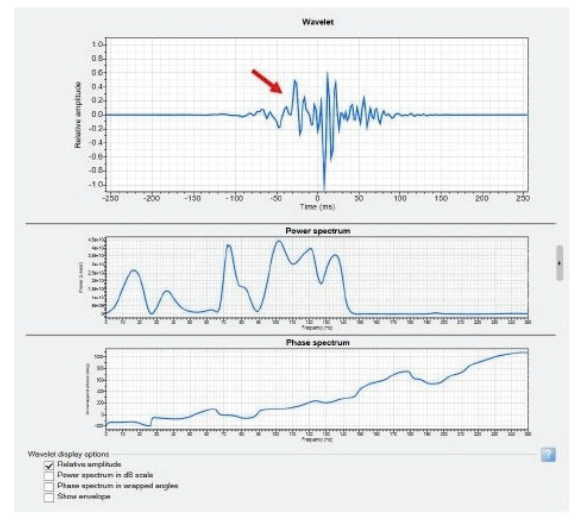

$$
\begin{aligned}
& \text { Wszystkie sygnały } \\
& \text { ekstrahowane w oparciu } \\
& \text { o krzywe z otworu Str-OU1, } \\
& \text { w zakresie } 1400 \div 1920 \mathrm{~ms} \\
& \text { (interwał sylursko-ordowicki) } \\
& \\
& \text { Zakres częstotliwości } \\
& \text { „centroidalnych" } \\
& 70 \div 150 \mathrm{~Hz}
\end{aligned}
$$

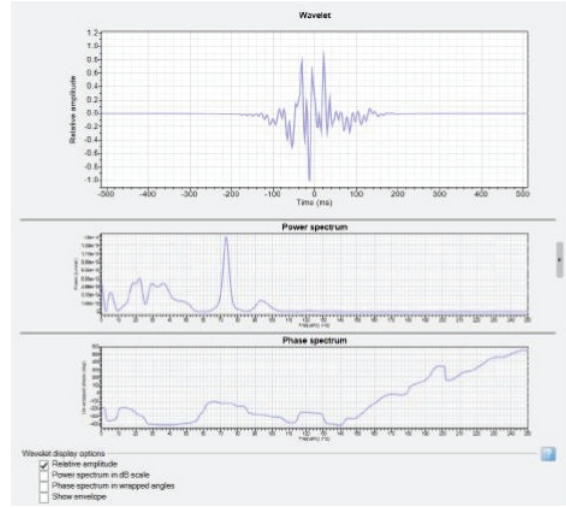

Zakres częstotliwości „centroidalnych” $60 \div 80 \mathrm{~Hz}$

Rys. 26. Porównanie sygnałów ekstrahowanych z zapisów sejsmicznych w wariantach W3 i W1 poddanych różnym opcjom modyfikacji

Jak piszą Piotr Łapinkiewicz i Jan Barmuta, na obrazie falowym zauważa się niekiedy regularne zakłócenia, wynikające najprawdopodobniej z propagacji sygnału o szerokim widmie i licznych side lobe'ach. Efekt ten jest bardziej widoczny na opcjach modyfikacji a, b, c, d-gdzie określono operator umożliwiający wprowadzenie szerokiego pasma wysokich częstotliwości. Na opcjach a-n, b-n, c-n, d-n, skupionych na niższych wartościach częstotliwości, efekt ten jest znacznie słabszy - niemniej, jak zresztą na większości materiałów sejsmicznych, właściwie bez względu na ich jakość, prowadzić może do błędnej interpretacji wykresów (rysunki 26, 27a, b).

Podobnie negatywnie oceniono efekt pojawiającego się układu amplitud o kształcie ,zygzakowatym”. Niemniej w konkluzji autorzy przekazują niejednoznacznie brzmiącą opinię: ,jest to efekt słaby, nieuniemożliwiajacy interpretacji strukturalnej”. Jako autorka rozwiązania czuję się w obowiązku dodać, że cytowany przypadek również nie zakłócał interpretacji litofacjalnej - bowiem jest łatwy w identyfikacji. Ponadto pokazuje, jak trudny jest niekiedy „dialog” interpretatora „samego z sobą", o czym w publikacjach polskojęzycznych wspomina się niezwykle rzadko, chociaż przynosi ważniejszy efekt edukacyjny niż omawianie wyłącznie przypadków pozytywnych.

Uzupełniając powyższe spostrzeżenie, należy dodać, że projektowanie operatora modyfikacji zazwyczaj ukierunkowane jest na określony interwał analizowanego obiektu (w niniejszym przypadku 1380 $\div 1940 \mathrm{~ms}$ - jak na wcześniejszym rysunku 24), stąd uwaga na temat przestrzeni poza celem geologicznym.

Kolejne przykłady efektywności zaproponowanego rozwiązania przytoczono za cytowanymi już wyżej realizatorami oraz P. Łapinkiewiczem i J. Barmutą na podstawie opracowania AGH: Wierzbica - porównawcza analiza wyników procedur zwiększania rozdzielczości zapisu sejsmicznego [12] - wykonana według rozwiązania zespołu INiG - PIB (Halina Jędrzejowska-Tyczkowska, Krystyna Żukowska, Irena Irlik) na 26 przekrojach sejsmicznych wzdłuż linii XL270, przechodzącej przez odwiert Str-OU1, dla dwóch wolumenów sejsmicznych W1 i W3, o różnych geometriach akwizycji.

Zadanie realizowano według dwóch różnych opcji aplikowanego operatora modyfikacji: w zakresie do $150 \mathrm{~Hz}$ (8 roz-

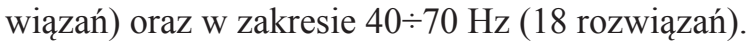

Sztuczne sekwencje refleksów pojawiające się na sekcji

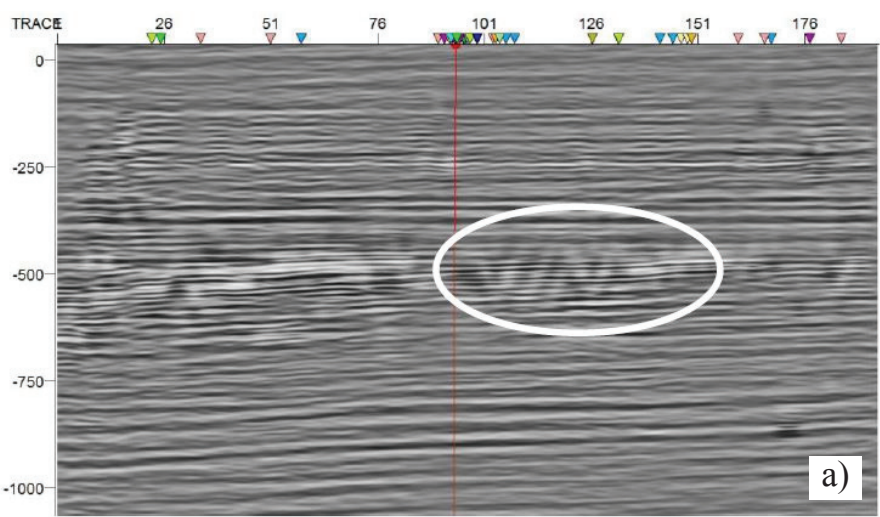

Rys. 27. Wyniki analizy efektów modyfikacji spektralnej przeprowadzonej przez P. Łapinkiewicza oraz J. Barmutę (według [11]) 
Wierzbica, sejsmika W3, x1270 - wersja wyniku an a) dla operatora modyfikacji $150 \mathrm{~Hz}$

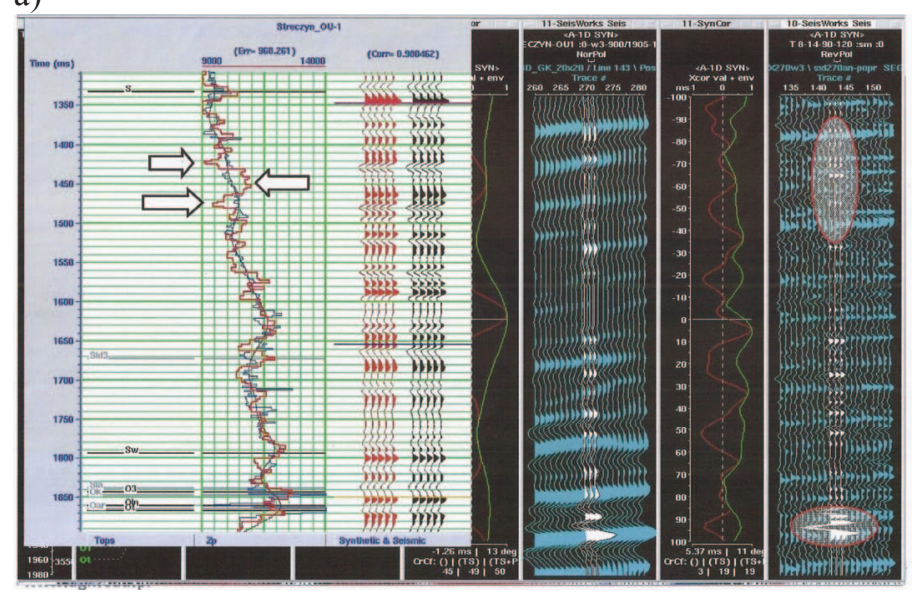

Wierzbica, sejsmika W1, x1270 - wersja wyniku acn b)

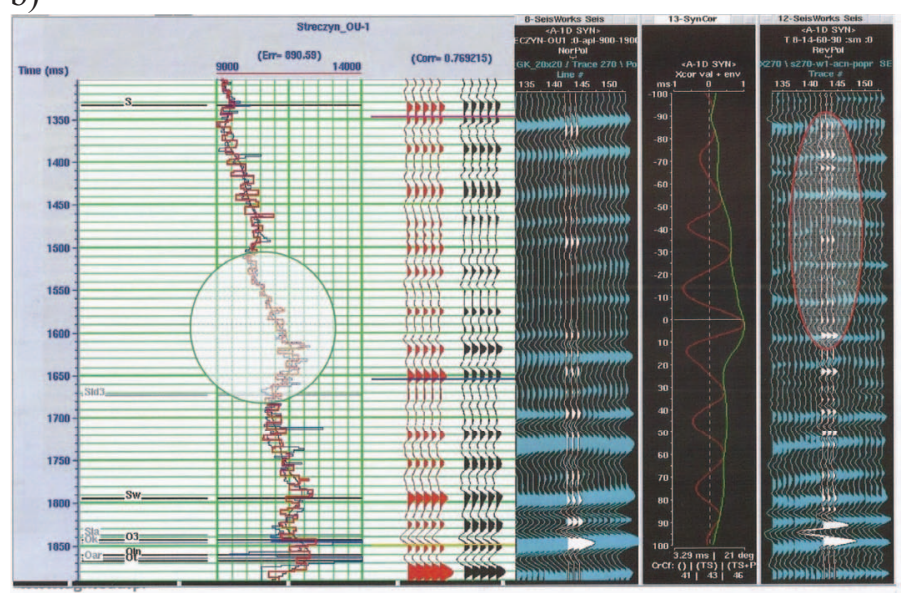

Rys. 28. Porównanie wyników zaaplikowania operatorów an (a) i acn (b) na wolumenach W3 i W1 (według [10])

Dwie z przedstawionych aplikacji: opcja an dla wolumenu W3 oraz opcja acn dla wolumenu W1 - poddane zostały dość szczegółowej analizie i porównane z danymi profilowań otworowych (rysunek 28a i b). Dla przypomnienia przywołać należy rysunek 17, na którym przedstawiono krótką charakterystykę kolejnych operatorów.

Celem przestawionych obliczeń była ocena możliwości zastąpienia efektów akwizycji i sumowania o wysokiej krotności przez dobranie stosownego operatora modyfikacji spektralnej.

Jak pokazuje analiza, porównanie krzywych przed modyfikacją (krzywa niebieska) danych z otworu Str-OU1 (krzywa czarna) oraz po inwersji (krzywa czerwona) z sejsmogramami syntetycznymi wariantów W3 (rysunek 28a) oraz W1 (rysunek 28b) - dane input (zestaw czerwony) oraz dane po modyfikacji (zestaw czarny) świadczy o braku konieczności rozszerzenia widma w wariancie 1 poza zakres $70 \mathrm{~Hz}$. Wskazuje też na możliwość uzyskania porównywalnego wy- niku na danych w wariancie 3 , ale przy rozszerzeniu operatora do $150 \mathrm{~Hz}$.

Rysunek 29 (a, b) przedstawia porównanie wariantów 3 i $1 \mathrm{w}$ opcji modyfikacji an i acn odniesionych do wstępnych (wstawionych w pozycji centralnej) wyników inwersji wariantu W1 przed modyfikacją.

$\mathrm{Na}$ rysunku 30 (a, b), będącym również efektem analizy wykonywanej przez zespół WGGIOŚ AGH [10] na temat efektywności rozwiązania zaproponowanego w zespole INiG - PIB, przedstawiono najbardziej ,ilościową” postać porównania podwyższenia rozdzielczości na poziomie przetwarzania (modyfikacja spektralna), jak też na poziomie akwizycji (schemat obserwacji oraz krotność sumowania). Krzywą impedancji akustycznej (kolor szary) zestawiono z krzywą inwersji wykonanej na danych sejsmicznych (rysunek 30a) w wariancie W3 przed modyfikacją (kolor niebieski) oraz z wynikami inwersji wykonanej po modyfikacji spektralnej an $(\sim 150 \mathrm{~Hz})$ i anc $(\sim 70 \mathrm{~Hz})$.
Porównanie wyników inwersji sejsmicznej dla rozwiązań w wersji an $(150 \mathrm{~Hz})$ i acn $(70 \mathrm{~Hz})$

a)

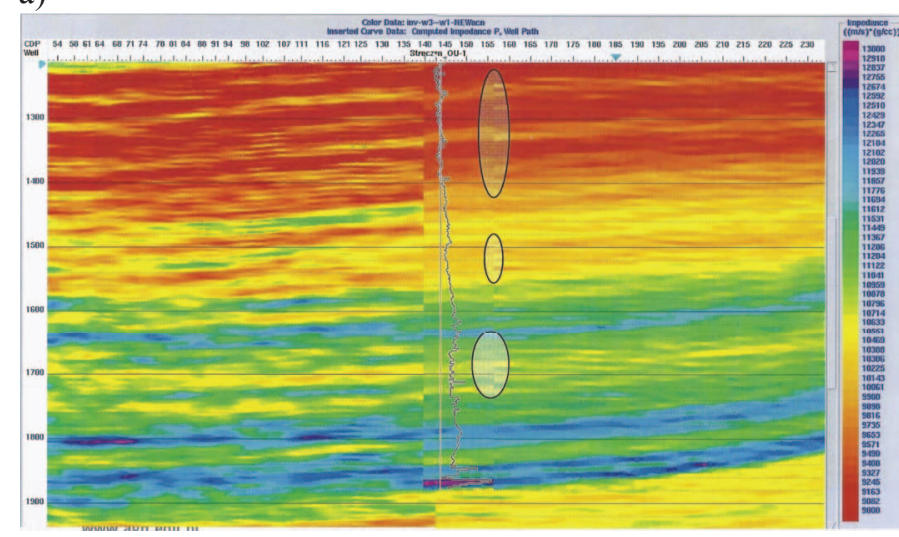

Porównanie wyników inwersji sejsmicznej dla rozwiązań w wersji an $(150 \mathrm{~Hz})$ i acn $(70 \mathrm{~Hz})$

b)

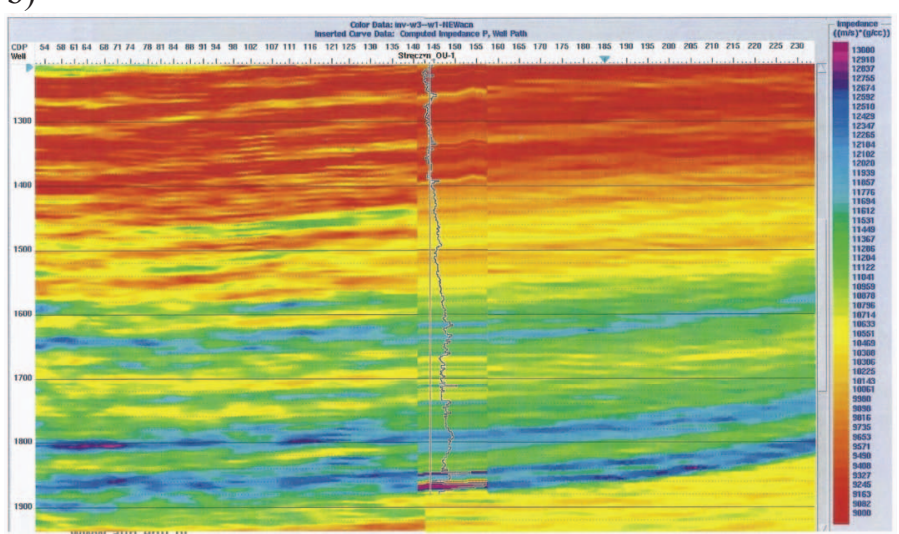

Rys. 29. Porównanie wyników inwersji sejsmicznej obliczonej dla danych sejsmicznych w wariantach W3 i W1 z zaaplikowaniem operatorów modyfikacji w opcjach an i acn oraz z krzywą AI o rozdzielczości dostosowanej do danych sejsmicznych (według [10]) 
Porównanie z trasą sejsmiczną input $\mathrm{W} 3$ (kolor czerwony) odtworzoną w śladzie otworu pokazuje, jak istotnie zaproponowane modyfikacje podnoszą rozdzielczość wolumenu sejsmicznego. Ponadto obliczenia wariancji dla wyników inwersji wskazują, że zbliżenie do interwału celu geologicznego, dla którego określony był operator modyfikacji (1340 $\div 1980 \mathrm{~ms})$, zmniejsza rozbieżności wyników; wartość wariancji istotnie maleje (horyzont $\mathrm{Sw}, \mathrm{Sla}, \mathrm{O} 3, \mathrm{O}$ ). Najmniej korzystnie w tym sensie przedstawia się interwał $1530 \div 1630 \mathrm{~ms}$, leżący zresztą poza obszarem celu geologicznego.

Podobną analizę wykonano dla wolumenu sejsmicznego w wariancie W1 (rysunek 30b) i dla analogicznych porównań. W przypadku tej wersji wyniki są bardziej korzystne.

Porównanie impedancji akustycznej - Str-OU1/x1270/i1143, sejsmika W1, wyniki inwersji dla wersji an (operator modyfikacji $150 \mathrm{~Hz}$ ) i acn (operator modyfikacji $70 \mathrm{~Hz}$ )

b)

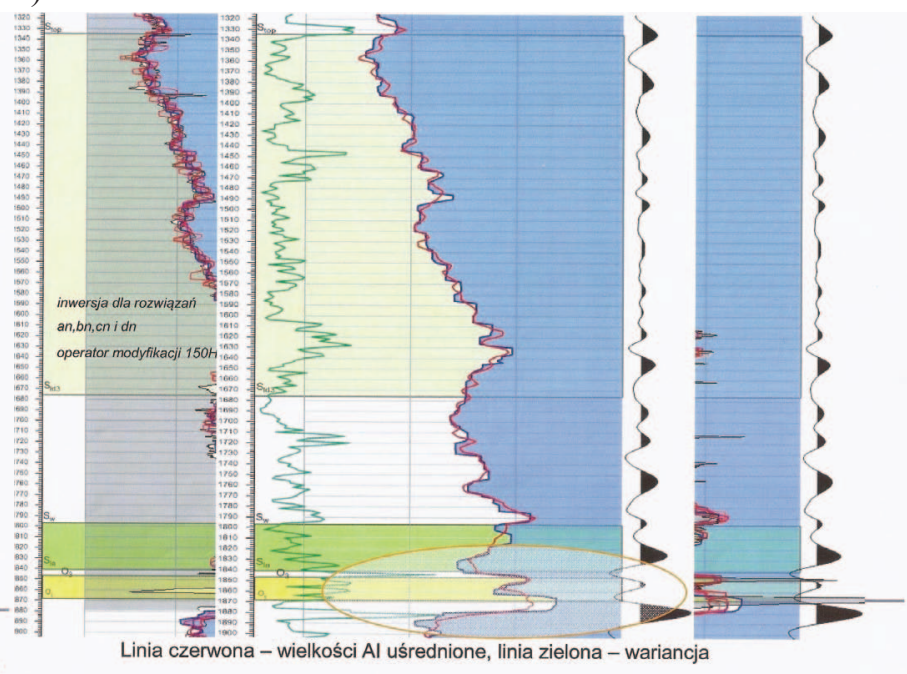

a)

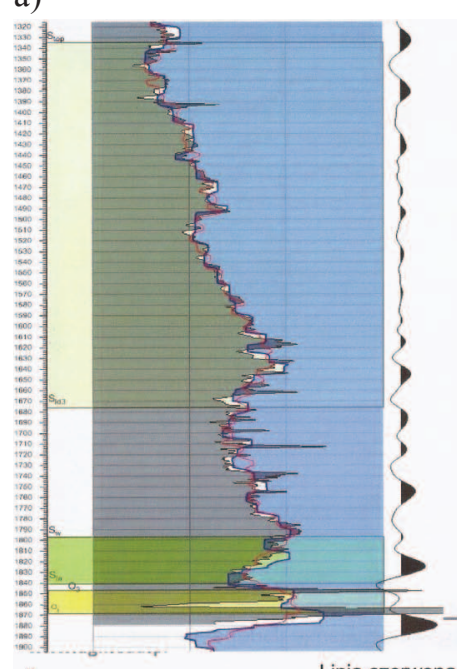

Linia czerwona - wielkości Al uśrednione, linia zielona - wariancja

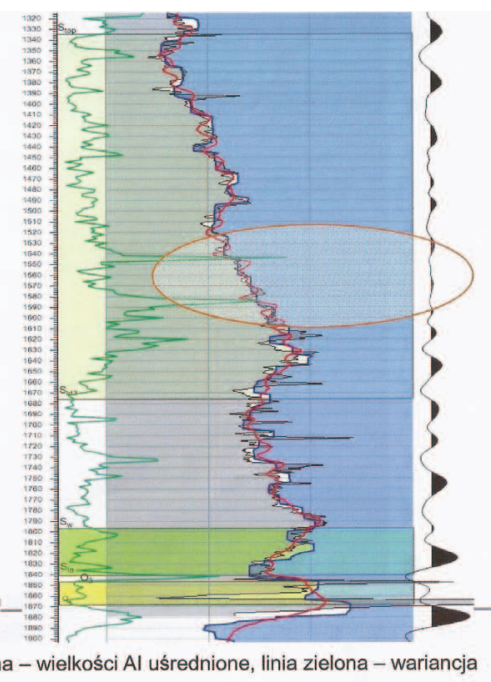

Rys. 30. Porównanie krzywej impedancji akustycznej z wynikami inwersji sejsmicznej obliczonej na danych sejsmicznych po modyfikacji spektralnej; a) wariant W3, opcja an i ac, b) wariant W1, opcja an i acn (według [10])

\section{Podsumowanie}

Przedstawiona w publikacji problematyka dotyczy jednego z najważniejszych zagadnień związanych z poprawnością interpretacji geologicznej danych sejsmicznych. I chociaż wszystkie elementy metodyki badań sejsmicznych są ważne - od akwizycji poczynając i poprzez procedury przetwarzania, obrazowania sejsmicznego, uwzględniania anizotropii, na różnych wariantach interpretacji kończąc - nie ulega wątpliwości, że podstawą poprawnego odtworzenia charakterystyki strukturalnej, stratygraficznej oraz litostratygraficzno-facjalnej jest rozwiązanie problemu prędkości. W tym zakresie bardzo często interpretator posługuje się różnymi technikami kalibracji dla utożsamienia obrazu przestrzennego ośrodka $\mathrm{z}$ istniejącymi wynikami danych otworowych. Upraszczając, in- terpretator z konieczności operuje w dwóch różnych środowiskach pomiaru, o czym pamiętać należy, uwzględniając efekt skali $[9,12]$. Przywiązywanie nadmiernej wagi do wartości bezwzględnych niektórych parametrów musi być traktowane z dużą ostrożnością. Poprawnie określone pole prędkości ma często decydujący wpływ na wyznaczenie wielu parametrów, m.in. petrofizycznych, złożowych, geomechanicznych, a nawet geochemicznych, estymowanych przestrzennie $\mathrm{z}$ danych sejsmicznych $[6-8,11]$.

W konkluzji przytoczyć należy znaną prawdę - prędkość związana jest z częstotliwością związkiem dyspersyjnym. Wszelkie porównania parametrów powinny być prowadzone na wspólnej platformie charakterystyki spektralnej.

Autorka dziękuje p. dr Krystynie Żukowskiej za napisanie programów i wykonanie obliczeń oraz p. Irenie Irlik za perfekcyjna graficznq wizualizację wyników.

Prosimy cytować jako: Nafta-Gaz 2018, nr 1, s. 3-21, DOI: 10.18668/NG.2018.01.01

Artykuł nadesłano do Redakcji 11.05.2017 r. Zatwierdzono do druku 12.09.2017 r. 
Prezentowane badania i uzyskane wyniki są efektem realizacji zadania wchodzącego w skład projektu BLUE GAS - Polski Gas Łupkowy pt.: Badania sejsmiczne i ich zastosowanie dla detekcji stref występowania gazu z łupków. Dobór optymalnych parametrów akwizycji i przetwarzania w celu odwzorowania budowy strukturalnej oraz rozkładu parametrów petrofizycznych i geomechanicznych skat perspektywicznych (GASLUPSEJSM); Zad. 2.: Poszukiwanie, rozpoznawanie - modelowanie i przetwarzanie danych sejsmicznych, w tym metodyka określania żądanej rozdzielczości sejsmicznego pola falowego w procesie lokalizacji, udostęniania i eksploatacji formacji łupkowych - praca INiG - PIB na zlecenie NCBiR; nr zlecenia 6110/SG, nr archiwalny: DK-4100-0601/07/13.

\section{Literatura}

[1] Berkhout A.J.: Utilization of multiple scattering: the next big step forward in seismic imaging. 77 EAGE Conference \& Exhibition, Madrid 2015, DOI: 10.3997/2214-4609/2014.12.936.

[2] Cyz M., Malinowski M., Krzywiec P., Mulińska M., Słonka Ł.: Application of high-resolution 2D-3C seismic for characterization of the perspective Jurassic shale play in Central Poland. Tectonophysics 2016, vol. 689, s. 4-13.

[3] Jędrzejowska-Tyczkowska H.: Dobór optymalnej rozdzielczości sekcji sejsmicznej na drodze analizy i modyfikacji charakterystyk spektralnych danych sejsmiki powierzchniowej i otworowej. Nafta-Gaz 2017, nr 8, s. 531-550, DOI: 10.18668/ NG.2017.08.01.

[4] Jędrzejowska-Tyczkowska H.: Nowe aspekty modyfikacji spektralnej pola sejsmicznego fal podtuznych z wykorzystaniem pomiarów prędkości fal poprzecznych $w$ otworze. Nafta-Gaz 2017, nr 11, s. 811-834, DOI: 10.18668/NG.2017.11.01.

[5] Jędrzejowska-Tyczkowska H.: Rozdzielczość danych sejsmicznych $w$ świetle możliwości modyfikacji domeny spektralnej pola falowego oraz wariantowości schematu i parametrów akwizycji na podstawie analizy danych syntetycznych. Nafta-Gaz 2017, nr 12, s. 907-917, DOI: 10.18668/NG.2017.12.01.

[6] Jędrzejowska-Tyczkowska H.: The influence of disturbances and noise of normal distribution on the correctness of geological interpretation of seismic sections with increased resolution. Nafta-Gaz 2015, nr 12, s. 59-71, DOI: 10.18668/ NG.2015.12.01.

[7] Jędrzejowska-Tyczkowska H.: Zastosowanie transformacji sygnatu elementarnego $w$ interpretacji danych sejsmicznych. Prace IGNiG 1998, nr 92, s. 1-115.

[8] Jędrzejowska-Tyczkowska H., Wilk A., Słota-Valim M.: Velocities Dispersion as a Possible Reason of Miscorrection of the Pressure Prediction Procedure via Seismic. First EAGE Workshop on Pore Pressure Prediction, Pau, France 19-21.03.2017.

[9] Jędrzejowska-Tyczkowska H., Ziemianin K.: Zagadnienie skali w zintegrowanym dynamicznym procesie poszukiwań, opisu oraz eksploatacji niekonwencjonalnych złóż węglowodorów. [W:] Rzeczpospolita tupkowa - Studium wiedzy o gazie tupkowym. Prace Naukowe INiG 2012, nr 183, s. 27-42.

[10] Kasina Z.: Teoria sygnału sejsmicznego. Wydawnictwo AGH, Kraków 2009.

[11] Łapinkiewicz P., Barmuta J.: Analiza materiałów INiG - w ramach realizacji projektu pt.: Badania sejsmiczne i ich zastosowanie dla detekcji stref występowania gazu z łupków. Dobór optymalnych parametrów akwizycji i przetwarzania w celu odwzorowania budowy strukturalnej oraz rozkładu parametrów petrofizycznych i geomechanicznych skat perspektywicznych (GASLUPSEJSM), programu Blue Gas - Polski Gas Łupkowy. AGH 17.08.2016 - prezentacja.

[12] Łapinkiewicz P., Barmuta J.: Wierzbica - porównawcza analiza wyników procedur zwiększania rozdzielczości zapisu sejsmicznego - w ramach realizacji projektu pt.: Badania sejsmiczne i ich zastosowanie dla detekcji stref wystepowania gazu z tupków. Dobór optymalnych parametrów akwizycji i przetwarzania $w$ celu odwzorowania budowy strukturalnej oraz rozkładu parametrów petrofizycznych i geomechanicznych skat perspektywicznych (GASLUPSEJSM), programu Blue Gas - Polski Gas Łupkowy. AGH 17.08.2016 - prezentacja.

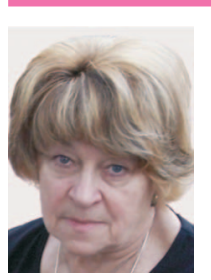

Prof. nzw. dr hab. inż. Halina JĘDRZEJOWSKATYCZKOWSKA

Instytut Nafty i Gazu - Państwowy Instytut Badawczy ul. Lubicz 25 A

31-503 Kraków

E-mail: tyczkowska@inig.pl 